\title{
Changing Prices in a Changing Climate: Electoral Competition and Fossil Fuel Taxation*
}

\author{
Jared J. Finnegan ${ }^{\dagger}$ \\ First draft: November 2018; This draft: April 2021
}

\begin{abstract}
When do governments increase the price of fossil fuels? Charting the theoretical territory between climate change politics and long-term policymaking, this paper highlights the role of electoral competition in shaping how politicians respond to the intertemporal tradeoff fossil fuel taxation represents. The more secure the government is in office, the more insulated it is from the vagaries of political competition, and the more likely it is to impose costs on constituents today to generate a future stable climate. By influencing governments' time preferences, competition structures the myopia of elected officials. I test the arguments using an original dataset of gasoline taxation across high-income democracies between 1988-2013. I find robust evidence that higher levels of electoral competition are associated with lower gasoline tax rates, and that the relationship is moderated by the level of costs imposed on voters, but not government partisanship. The analysis points to a crucial mechanism that plausibly accounts for the differential ability of governments to tackle a wider range of long-term policy challenges.
\end{abstract}

Keywords: Climate change, fossil fuel taxation, long-term policymaking, electoral competition, policy myopia

\footnotetext{
*For their very helpful comments, I thank Julius Andersson, Dan Berliner, Björn Bremer, Cathie Jo Martin, Marion Dumas, Lior Herman, Robert Keohane, Tobias Kruse, Jonas Meckling, David Soskice, Kai Spiekermann, David Vogel and Joachim Wehner, as well as colleagues at the Niehaus Center for Globalization and Governance at Princeton University and the Grantham Research Institute on Climate Change and the Environment, as well as audiences at the London School of Economics, 2017 MPSA Annual Conference, and 12th Annual Graduate Conference at the Hebrew University of Jerusalem.

${ }^{\dagger} \mathrm{UC}$ Berkeley and Grantham Research Institute on Climate Change and the Environment, LSE.
} 


\section{Introduction}

Climate change is one of the most significant long-term policy challenge facing governments. To address it, economists have, for decades, advocated carbon pricing (Nordhaus 1977). Increasing the price of fossil fuels should reduce their consumption and attendant carbon dioxide $\left(\mathrm{CO}_{2}\right)$ emissions. However, despite its theoretical elegance and wide diffusion in climate policy discourse (Meckling and Allan 2020), politicians have been slow to take up such advice. By some estimates, 85 percent of global greenhouse gas emissions remain unpriced (High-Level Commission on Carbon Prices 2017). The OECD has found that only 10 percent of emissions are priced at or above 30 Euros per tonne - the lower-end estimate needed to meet the objectives of the Paris Agreement (OECD 2016).

One explanation for this lack of enthusiasm is that vote-seeking politicians are reticent about drawing the ire of voters who prefer low energy prices (Rabe 2010, 2018). Indeed, a large body of survey research consistently finds that individuals dislike costly climate policies (e.g., Ansolabehere and Konisky 2014; Bechtel and Scheve 2013; Drews and Bergh 2015; Jagers and Hammar 2009; Shwom et al. 2010). Beyond the ballot box, governments are fearful of mass protest in response to tax rate hikes, such as recent ones by the gilets jaunes in France.

The political calculus of imposing costs may be improved if the associated benefits arrive quickly to voters; since voters and politicians tend to be impatient, preferring policy benefits that arrive earlier in time (Jacobs and Matthews 2012; Sheffer et al. 2017). However, the primary benefit of carbon pricing - a stable climate - is a diffuse, global public good generated over decades. Further complicating matters, avoided climate change is the absence of future harm, rather than an increase in an easily understood and tangible consumption good, such as healthcare, infrastructure, pensions, or education. Even ancillary benefits of climate mitigation, such as green jobs or innovation, are likely to only be manifest in the medium term. In this way, fossil fuel taxation constitutes a type of intertemporal redistribution -

short-term costs are borne today for benefits that arrive in the future (Finnegan 2019; Jacobs 
2011).

Considering these impediments, we can see why the politics of carbon pricing have proven tumultuous (Rabe 2018). Indeed, a perennial critique of democratic politics is that, being motivated primarily by re-election, politicians are systematically unable to see beyond the next contest. Instead of making tough choices today, they appeal to voters' shortsightedness, put off any sacrifice for as long as possible, and ignore the future consequences (Jacobs 2011; Boston 2016). Yet while the myopic pressures of democratic politics are daunting, the actual record of fossil fuel taxation presents a more complicated story.

As I show in this paper, fossil fuel tax rates vary widely across the high-income democracies and within them over time. In some countries, such as the Netherlands and Belgium, tax rates increase almost every year while rates have remained virtually unchanged for decades in the US and Canada. What explains this variation? Why are some governments willing to invest in long-term climate policies, like fossil fuel taxes, even at the risk of imposing short-term costs on their constituents? Surprisingly, we still do not know much about the answers to these questions. Despite its self-evident importance and the centrality of politics, climate change has remained curiously absent as a mainstream concern for political science (Keohane 2015).

This article investigates the reasons for the puzzling variation in fossil fuel tax rates by charting the largely unexplored theoretical territory between comparative climate change politics and research from political science and economics on long-term policymaking. It focuses on the role of the electoral environment in structuring politicians' time preferences. The basic argument is that the more secure the government is in office, the more insulated it is from the vagaries of political competition, and therefore the more likely it is to increase fossil fuel taxes. By shaping the incentives of elected officials to impose direct and highly visible costs on voters today, electoral competition informs how governments come to value the future benefits of climate mitigation. In this way, electoral competition shapes politicians' discount rates, and by extension their policy myopia. 
To test the theory, I analyze taxation of an important and widely consumed fossil fuel: gasoline. Gasoline is one of the largest sources of carbon pollution worldwide. In the US, for example, it accounted for 22 percent of energy-related $\mathrm{CO}_{2}$ emissions in 2018; on par with coal (U.S. Energy Information Administration 2020). For this reason, gasoline taxes have been highlighted as one of the most important fossil fuel taxes adopted to date (Sterner 2007), yet pricing policies around the world have been mixed (Ross, Hazlett, and Mahdavi 2017).

Utilizing an original dataset of gasoline excise tax rates and a measure of electoral competition developed using loss probability data from Kayser and Lindstädt (2015), I examine the relationship between competition and taxation within twenty high-income democracies between 1988 and 2013 using fixed effects regression models. I find robust evidence that higher levels of electoral competition are associated with lower gasoline tax rates, even after controlling for a wide range of potential confounders. Furthermore, the negative influence of competition is moderated by politicians' perceptions of voter preferences. When a tax increase is expected to impose high costs on their constituents, because gasoline consumption is widespread, politicians are even less likely to increase rates. Perhaps surprisingly, I find that government preferences play little role in shaping tax rates. Taken together, the results provide strong evidence that electoral competition structures politicians' strategic decision-making regarding long-term climate policies like fossil fuel taxation.

The paper contributes to the academic and policy literature in several ways. First, the paper contributes to the emerging subfield of comparative climate politics (Harrison and Sundstrom 2010; Hughes and Urpelainen 2015; Lipscy, forthcoming; Mildenberger 2020; Wood et al. 2019) - an under-researched area (Cao et al. 2014 Keohane 2015). While important research has focused on the politics of fossil fuel taxation in particular jurisdictions (e.g., Andersen 2019; Harrison 2012, Rabe 2010, 2018), this paper provides one of the first general theoretical frameworks. The arguments import previously overlooked insights from the long-term policymaking literature (Garrett 1993; Jacobs 2011, 2016) and economics 
(Azzimonti 2015; Nordhaus 1975) to highlight the key role of politicians' time preferences in shaping the politics of carbon taxation. Empirically, it is one of a very small handful of quantitative studies to examine environmentally-related taxation (to my knowledge, the only other being Ward and Cao (2012)).

Second, the paper contributes to broader debates in political science and economics about the extent to which electoral competition has a myopic effect on politicians' behavior (Alesina and Tabellini 1990; Cronert and Nyman 2021; Hübscher and Sattler 2017; Immergut and Abou-Chadi 2014 Nordhaus 1975; Schultz 1995). To date, scholars have generally analyzed aggregate taxing and spending decisions, which can be blunt measures of political decisionmaking. By examining one tax policy decision with intertemporal redistributive consequences, this analysis provides a sharp empirical test of competition's myopic effects.

From a policy perspective the paper has practical implications for addressing climate change. Increased fossil fuel prices are often thought to be necessary to shift production and consumption onto a more sustainable path. However, in democracies, such policies are likely to face strong political headwinds if elections are highly competitive and fossil fuel consumption is diffuse. Policymakers should take these electoral incentives into account when designing and implementing carbon taxes.

\section{The puzzle of fossil fuel taxation}

Since Nordhaus (1977), a tax on fossil fuels has been consistently advocated by economists as the most cost-effective policy to reduce $\mathrm{CO}_{2}$ emissions. By increasing the price of fossil fuels, taxes should reduce their consumption and associated emissions [ The idea gained traction and diffused widely, especially in the 1990s (Meckling and Allan 2020). In the case of transportation, fossil fuel taxes are arguably "the single most powerful climate policy instrument adopted to date" (Sterner 2007, 3194). Without them, fuel demand and $\mathrm{CO}_{2}$ emissions would be much higher.

1. Studies have found that carbon taxes are indeed effective in reducing emissions (e.g., Andersson 2019). 
Despite the theoretical elegance of taxes, the politics of have proved tumultuous (Rabe 2018). Politicians in Nordic countries were early adopters of carbon taxes and have been able to steadily increase rates over time, though not without conflict (Andersen 2019; Kasa 2000; Mildenberger 2020). In British Columbia and Ireland, politicians had similar success in adopting carbon taxes in the late 2000s, but less success increasing rates (Convery, Dunne, Joyce, et al. 2014, Harrison 2012 Rabe 2018). In the UK, rates for some fossil fuels were sharply increased in the 1990s, only to be halted amid protests in 2000 (Ekins et al. 2010). By 2013, Prime Minister David Cameron was demanding that his ministers get rid of green levies he believed were responsible for pushing up energy prices (Carter and Clements 2015). An "eco-tax" was adopted in Germany in 1999 as part of a broader environmental tax reform package; though it has not been increased since 2003 (Beuermann and Santarius 2006). In response to gilets jaunes protests in 2018, French politicians postponed planned increases in carbon tax rates. In Australia, a carbon pricing scheme was adopted in 2011 only to be repealed in 2014 (Rabe 2018). In the US, efforts to adopt an energy tax in 1993 fell flat, reflecting a marked aversion amongst politicians to directly impose costs on voters, which has kept fossil fuel taxes exceptionally low (Mildenberger 2020; Rabe 2010, 2018).

This rich literature offers important analyses of the political challenges of fossil fuel taxation in particular cases. However, we are still missing a general theoretical account that can explain why there has been such little implementation of what is widely considered to be the first-best policy to address climate change. Scholars have argued that vote-seeking politicians have few incentives to impose direct and highly visible costs on voters who, consistent with extensive survey research, dislike increased fuel taxes (Harrison 2012; Kasa 2000; Rabe 2010; 2018). Yet this reasoning cannot explain the variation in fossil fuel tax rates that we observe. As I show below, rates vary widely across the high-income democracies. What is more, apart from Ward and Cao (2012), there are few large-N investigations of the political drivers of environmental taxation across countries, which limits the generalizability of existing studies. 


\section{Electoral competition and fossil fuel taxation}

The starting point for the argument is to consider the sharp intertemporal tradeoff politicians face when considering fossil fuel taxes. Taxes impose concentrated costs today on constituents for the globally diffuse benefit of a hospitable future climate; while doing nothing about climate change imposes diffuse costs in the future for concentrated benefits enjoyed today in the form of low energy prices. By entailing short-term pain for long-term gain, taxes are a type of long-term "policy investment" that redistributes resources intertemporally (Finnegan 2019; Jacobs 2011). A number of factors should influence how politicians' make intertemporal tradeoffs (Finnegan 2019; Jacobs 2011, 2016). I focus on the way that the electoral environment shapes incentives to impose short-term costs on voters for benefits that arrive in the future

I assume that politicians are concerned first with re-election and second with implementing their preferred policies. There are at least four reasons why governments may prefer to increase fossil fuel taxes. Since the late 1980s, all governments in high-income democracies have faced common international pressure to address climate change. Being "Annex I" parties to the United Nations Framework Convention on Climate Change, they agreed to identical emissions reduction goals at the Rio Earth Summit in 1992 and signed the Kyoto Protocol in 1997 (though not all ratified it). Politicians have also at times faced pressure from voters and social movements to act. Given that fossil fuel taxes have been widely advocated as the first-best climate policy, governments may implement them to respond to these international and domestic demands. Some parties may also be ideologically committed to addressing climate change, for example green parties. Furthermore, governments can be motivated by an incentive to maximize revenues, in an effort to fund other policy programs or meet budget shortfalls (Beramendi and Rueda 2007; Berry and Berry 1992; Geschwind 2017; Levi 1989).

In line with previous scholars, I assume that voters will tend to be opposed to government

2. While important, I leave aside a discussion of the politics of imposing costs on industry. 
efforts to increase tax rates. First, fossil fuels are widely consumed. Any direct tax will impose highly visible costs on households - either at the pump or on electricity bills. A large body of survey research consistently finds that individuals' support for climate change policy, especially taxes, decreases as the personal costs of the policy rise (e.g., Ansolabehere and Konisky 2014; Bechtel and Scheve 2013; Drews and Bergh 2015; Jagers and Hammar 2009; Shwom et al. 2010). Second, negativity bias tends to focus individuals' attention on negative information (short-term costs) rather than positive (long-term benefits), while loss-aversion means they tend to weigh potential losses more than prospective gains of equal size (Jacobs 2011, Ch.2; Kahneman, Knetsch, and Thaler 1991). Last, there is evidence that voters are moderately impatient and distrust that politicians will keep their promise to deliver future benefits, preferring instead policy benefits that arrive more quickly, which further biases them against taxes that involve intertemporal tradeoffs (Jacobs and Matthews 2012).

As a consequence, politicians should view directly increasing fossil fuel prices via taxation as entailing some level of political risk. Indeed, consistent with a basic retrospective model of electoral accountability, there is evidence that voters tend to punish politicians at the next election for tax increases (e.g., Kone and Winters 1993), as well as stringent climate policies more generally (Stokes 2016). Additionally, fuel price increases are fertile ground for mass protest, with the most recent example being the gilets jaunes in France who, as mentioned above, took to the streets in opposition to a planned carbon tax increase.

While all elected officials should be weary of such risk, their risk tolerance should not be uniform. Instead, it should vary depending on political conditions. Crucially, how competitive they expect the upcoming election to be should structure their appetite for electoral risk. A more competitive election means higher uncertainty about a change in government control at the next contest from the perspective of the governing party(ies) (Blais and Lago 2009; Boyne 1998; Kayser and Lindstädt 2015; Strom 1990). Politicians certain to win or lose face low electoral competition, while those with a 50 percent probability of winning face 
high competition.

Competition should shape both the willingness of governments to adopt long-term policies (i.e., their myopia) and their ability to do so. When competition is low because the governing party is likely to win, a surplus of committed voters insulates it against marginal losses in vote shares that can result from electoral backlash. This increases its level of electoral safety, making it less risky to adopt policies that are costly in the near term, but promise future benefits. At the same time, high electoral safety lengthens governments' time horizons by enabling them to focus their attention on long-term challenges rather than solely winning the next election. What is more, because politicians expect to stay in office, they can also expect to claim credit for any medium-term environmental benefits that arise from fossil fuel taxation, as well as take advantage of the associated revenues. Lastly, putting up taxes means they may not need to increase them during the next term when their electoral fortunes might change. It is under these conditions that fossil fuel tax increases should be most likely.

Conversely, when competition is high, small changes in vote shares can remove the governing party from power. Knowing this, the party's vote-seeking preferences should dominate, and generate strong incentives to pursue a strategy of short-term vote-maximization in an effort to win the next contest. Under these conditions, long-term policy investments that could upset voters today, such as fossil fuel taxes, are unlikely to be adopted. The low probability of adoption is compounded by uncertainty about whether the party will remain in office long enough to reap any associated benefits.

When competition is low because the government is likely to lose, expectations are less clear. The party is insulated and can therefore afford to be far-sighted in its policymaking and pursue tax increases without fear of electoral backlash. Furthermore, by increasing rates it can try to lock in its preferred policy and constrain an adversarial successor's room to maneuver (Alesina and Tabellini 1990). However, in the case of fossil fuel taxes, putting up rates might also expand a successor's options. It can absolve them of the need to enact a painful policy choice, offer a new revenue stream, and give them the option to cut taxes 
to gain political capital. Anticipating this, the governing party may instead choose not to touch rates.

By structuring their responsiveness to voter preferences today, electoral competition shapes politicians' discount rates, or the extent to which they value future policy benefits against current political risk. Importantly, this effect should be casually prior to government preferences. While governments may have a variety of motivations to increase fossil fuel taxes, as described above, the first priority of all governments is re-election. Governments across the ideological spectrum should respond to increasing competition by reducing, or at least not increasing, rates.

The arguments import previously overlooked insights from long-term policymaking research to theorize the politics of fossil fuel taxation. Garrett (1993) is perhaps the first to argue that "it is only governments that are relatively secure in office that can assume the longer-term time horizon necessary... to engage in the politics of structural change", pointing to the creation of the Swedish welfare state and Thatcher's neoliberal reforms in the UK as examples. Jacobs (2011) theorizes that low levels of electoral competition are a necessary condition for long-term policy investments, citing evidence from pension reforms. More recently, researchers have shown how electoral vulnerability shapes long-term reforms like welfare state retrenchment (Immergut and Abou-Chadi 2014) and fiscal consolidation (Hübscher and Sattler 2017). Lastly, from the economics literature, Azzimonti (2015) demonstrates formally how lower competition decreases the discount rate of policymakers, resulting in higher levels of public investment. More broadly, the theory is consistent with work on political business cycles that connects high electoral competition with increased efforts by incumbents to manipulate macroeconomic policy (e.g., Nordhaus 1975; Schultz 1995) or constrain the behavior of the next government (e.g., Alesina and Tabellini 1990).

Before moving on, one additional point is needed. The assumption that politicians will always view voters as uniformly opposed to fossil fuel tax increases can be relaxed. Indeed, we should expect the negative effect of competition to be moderated by governments' perceptions 
of voters' tax preferences. I explore this possibility in further detail below.

\section{Methods}

\subsection{Research design}

To test the arguments, I examine the relationship between electoral competition and one widespread type of fossil fuel taxation - gasoline taxes - in twenty high-income democracies between 1988 and 2013 [3 While the problem of climate change has been known to governments since at least the 1960s, it is starting around 1988 that governments began to take serious action (Finnegan 2019, Ch 1). That year the World Conference on the Changing Atmosphere in Toronto marked the first major international, multilateral conference focused on policy solutions. In addition, governments began to convene expert commissions to develop domestic mitigation policies, including fossil fuel taxation, in countries like Germany and Sweden.

Gasoline is a major source of carbon pollution across the high-income democracies. Consequently, gasoline taxes are arguably the single most important fossil fuel tax they have adopted (Sterner 2007). In practical terms, gasoline is widely consumed by voters across the sample of countries and over time, which is not the case for other fossil fuels, such as coal, natural gas, or heating oil. Moreover, motorists frequently visit gasoline stations to fill up, making changes in gasoline prices highly visible to voters. For these reasons, gasoline represents an ideal case for analyzing the political economy of directly taxing a fuel that is consumed frequently and extensively by voters.

Governments have a number of policy design options when increasing taxes on gasoline. They may simply increase existing excise or value-added tax rates (VAT) or adopt an energy tax (a flat tax based on the energy content of the fuel), an environmental tax (typically an

3. Australia, Austria, Belgium, Canada, Denmark, Finland, France, Germany, Greece, Ireland, Italy, Japan, New Zealand, Netherlands, Norway, Portugal, Spain, Sweden, UK, and US. 
excise tax by a different name), or an explicit "carbon tax" (a flat tax based on the carbon content of the fuel). Indeed, all carbon taxes imply a tax on gasoline. Virtually every carbon tax adopted by the sample of countries is applied to gasoline (see online appendix).

Table 1: Nominal changes in gasoline tax rates (national currencies) (1988-2013)

\begin{tabular}{lll}
\hline \hline Rate change & Freq. & Percentage \\
\hline Decrease & 35 & 6.93 \\
No change & 238 & 47.13 \\
Increase & 232 & 45.94 \\
\hline Total & 505 & 100 \\
\hline \hline
\end{tabular}

Because VAT rates vary little over time and not all countries have them, I analyze excise taxes. All countries in the sample have adopted excise taxes, offering variation across space and time. To measure rates, I compile an original dataset of excise tax levels per liter of gasoline in national currencies that draws on a variety of national and international sources, such as the International Energy Agency, government ministries, and national tax authorities. ${ }^{4}$ In addition to standard excise taxes, the measure includes all carbon, energy, and other special environmental taxes applied to gasoline.

Table 1 shows the frequency of rate changes across the sample. We see that governments have tended to either not change tax rates (47 percent of country-years) or increase them (46 percent). Very rarely are they decreased (7 percent). However, there is wide variation by country. The US and Japan have increased their rates only twice since 1988, whereas Norway increased them in 24 of 26 years.

4. See online appendix for data sources. 
Figure 1: Trends in gasoline taxation

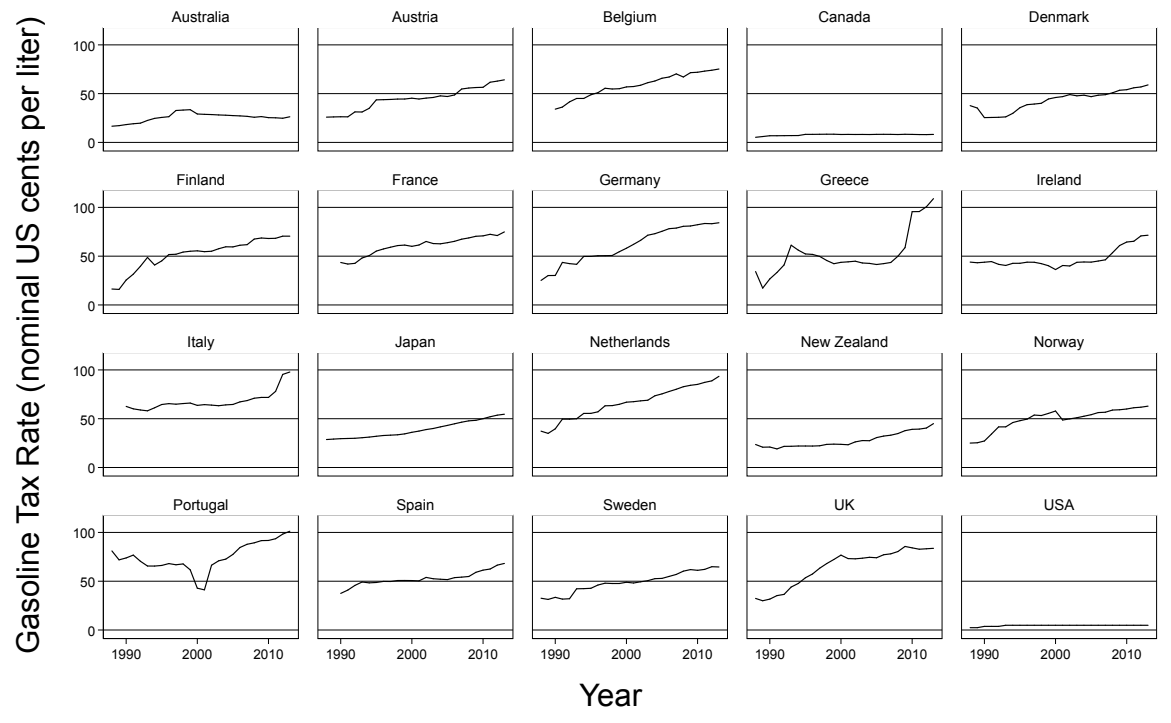

Graphs by Country

\subsection{Operationalizing key variables}

To measure gasoline taxes in a cross-nationally comparable way I convert national currency rates into a common unit - nominal US cents per liter - using USD purchasing power parity exchange rates (Figure 1). I use nominal rather than real rates to capture the behavior of politicians, since this is the phenomenon that my arguments seek to explain. Politicians only have direct control over the nominal rate. Moreover, it is nominal increases that are politicized during election campaigns (Li, Linn, and Muehlegger 2014).

While the measure captures tax levels across countries in a comparable way over time, the drawback is that some artificial variation is introduced from exchange rate fluctuations, which are largely independent of tax decisions by politicians. To minimize measurement error, I include three macroeconomic controls that influence exchange rates: inflation, public debt, and economic growth

The average tax rate for the sample is about 47 cents per liter and the median is around

5. While using tax levels is the preferred approach, re-estimating the models using percent changes in national currency rates $\left(\Delta\right.$ tax rate $_{i, t} /$ tax rate $\left._{i, t-1}\right)$ does not substantively change the results (see online appendix). 
49 cents, indicating a relatively normal distribution. Rates increase across all countries from 1988 to 2013, though the magnitude varies considerably. Increases are modest in Australia, Canada, Spain, and the US and most dramatic in Belgium, Germany, Greece, and the Netherlands. The US has the lowest rate in the sample (2.4 cents per liter in 1988-89), while Greece has the highest (109 cents in 2013).

An ideal measure of electoral competition would be based on incumbent perceptions of their re-election prospects at the time they are considering gasoline tax changes (Boyne 1998; Cronert and Nyman 2020). However, given the difficulty of gathering such data, I instead rely on a proxy measure of loss probability developed by Kayser and Lindstädt (2015). Conceptually, the measure captures the "expected probability that the plurality party in parliament loses its seats plurality in the next election" from the perspective of that party (Kayser and Lindstädt 2015, 243). It is a function of two elements. The first is the expected volatility of a party's national vote share at the next contest, estimated using vote swings in the past six elections. The assumption is that politicians predict vote swings in the upcoming election based previous outcomes. By accounting for voter volatility, the measure better captures electoral risk than common alternative measures like vote or seat margins. Indeed, as Kayser and Lindstädt point out, what constitutes a safe margin in the Netherlands, where volatility is low, means little electoral security in Canada, where volatility is high.

The second element is a country's seats-votes elasticity, or the extent to which changes in vote shares generate changes in seat shares. It depends on electoral rules and the geographic distribution of each party's voters. For parties in proportional (PR) systems, seats-votes elasticities are equal to one. However, in majoritarian systems they are estimated using votes and seats data from the most recent election. Elasticities range from 1.88 for the US Democratic Party in the 1988 election to 3.98 for the Australian Labor Party in 1990. A plurality party faces higher loss probability when it expects a vote swing large enough to remove its plurality status, as a result of expected changes in voter volatility and/or the 
geographic distribution of votes.

Loss probabilities are forward-looking and capture the view of the dominant policymaker regarding the electoral security of their position. Moreover, because they are estimated from previous elections they should enjoy exogeneity from gasoline tax changes in a given term. While there is a spirited debate on the best measure of electoral competition (Abou-Chadi and Orlowski 2016; Blais and Lago 2009; Cox, Fiva, and Smith 2020; Cronert and Nyman 2020), this data offers the most complete and well-developed proxy of competition for the countries in my sample. It enables me to overcome data limitations that have previously prevented climate politics researchers from directly testing the effects of loss probability (e.g., Aklin and Urpelainen 2013). The major drawback is that values change only in election years, and therefore do not capture dynamic changes in politicians' perceptions of electoral risk in years between elections. Furthermore, there is limited coverage for Italy, Japan, and New Zealand due to their electoral system changes in the 1990s.

Kayser and Lindstädt estimate loss probabilities for the plurality party in the legislature. While this party is typically also the governing party, in some cases it is not. Still, given the zero-sum nature of elections and because vote swings are estimated using data for the two largest parties, I assume that loss probabilities indicate the competitiveness of the overall electoral environment and therefore utilize the full dataset 6

Electoral competition is highest at middle values of loss probability. It is around these values that plurality parties should be most responsive to the electorate in an effort to maximize votes and secure electoral success. To measure electoral competition, I therefore use Formula 1 to calculate the absolute distance of each plurality party's loss probability from 0.5 , or theoretically perfect competition, and then rescale the variable to a range of 0 to 1 , where 1 is equal to perfect competition:

$$
\left[\left(1-\mid \text { lossprobability }_{i, t}-0.5 \mid\right) / 0.5\right]-1
$$

6. The results are also robust to limiting the sample the prime minister's party only (see online appendix). 
Figure 2: Trends in electoral competition

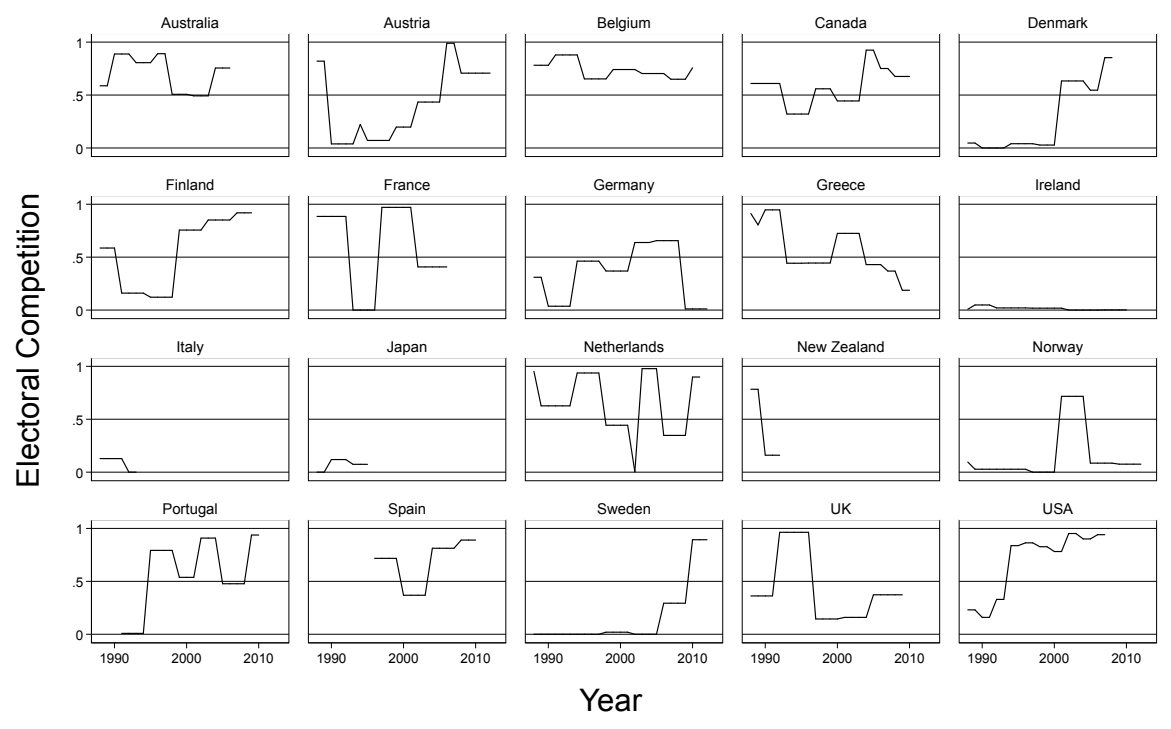

Graphs by Country

This new measure assumes that parties with a low probability of losing the next election (i.e., "likely winners" with a loss probability below 0.5) and those with a high probability of doing so (i.e., "likely losers" with a loss probability above 0.5 ) behave similarly. In an effort to maximize their chances of winning, both act myopically and refrain from putting up taxes as their loss probability moves toward 0.5. Empirical tests provide evidence that there is no statistical difference between the behavior of likely winners and likely losers (see online appendix). I therefore proceed with the measure. However, given mixed theoretical expectations, I separately analyze the behavior of likely winners and likely losers in Section 5.3 below.

Figure 2 shows the new measure of electoral competition. Mean competition for the sample is 0.44 with a standard deviation of 0.34 . On average, electoral competition is highest in Belgium and Australia and lowest in Ireland, Norway, and Sweden. 


\subsection{Model specification and controls}

There is generally a lag between when politicians adopt tax increases and when they implement them. Rates tend to be set in the current year and implemented in subsequent years. For example, the Swedish government adopted its carbon tax in 1990 and implemented it in 1991 (Andersson 2019). I therefore assume that the tax rate in time $t$ is a result of political decisions made, and information available, in time $t$-1. To model this delay, I lag all variables one year apart from the electoral cycle.7 As mentioned, loss probabilities are calculated using data from previous elections. There should therefore be little endogeneity between the measure of electoral competition and gasoline tax rates, especially once lagged.

I estimate OLS models of the form

$$
Y_{i t}=\beta_{1} X_{i t-1}+\beta_{2} \mu_{i t}+\theta C_{i t-1}+\alpha_{i}+v_{t}+\epsilon_{i t}
$$

where $\mathrm{Y}_{i t}$ is the nominal tax rate level (US cents per liter) in country $i$ in year $t$; $\mathrm{X}_{i t-1}$ is electoral competition lagged one year, $\mu_{i t}$ is the electoral cycle, $\mathrm{C}_{i t-1}$ is a vector of lagged control variables, $\alpha_{i}$ are country fixed effects, $v_{t}$ are year fixed effects, and $\varepsilon_{i t}$ is the error term.

I include two sets of controls. The first control for differences in tax policy preferences across governing parties. Depending on their partisanship, governments may be more or less inclined to adopt tax increases. To control for political party, I include the percentage of cabinet seats held by green parties and the percentage held by non-green left parties. To control for differences in fiscal health, which may push governments to maximize tax revenues in an effort shore up their finances, I include measures of the budget deficit and public debt as a percentage of GDP (Berry and Berry 1992; Geschwind 2017). To control for the influence that oil sector companies and unions may exert on governments, I include domestic oil production per capita (Ward and Cao 2012).

7. Using a two-year lag structure does not alter the results (see online appendix). 
The second set of controls includes factors that may influence political opportunities for tax rate increases. The large literature on political business cycles predicts that governments should be less likely to increase taxes as elections draw near (e.g., Nordhaus 1975). To control for this possibility I include a dummy for election years. I control for inflation since times of inflation may provide cover to increase taxes or tax increases may be indexed to inflation (Berry and Berry 1992; Goel and Nelson 1999). Nominal GDP growth is included to control for national economic shocks that may affect voters' sensitivity to fuel price increases (Berry and Berry 1992). I include gasoline VAT rates to control for fuel taxation apart from excise taxes. Lastly, I control for the saliency of environmental issues across the political system by calculating the average pro-environmental stance across all parties in each country-year using data from the Comparative Manifestos Project (per501). The measure should also provide a proxy for environmental issue salience amongst voters, since issue attention amongst parties should, to some extent, reflect that of voters. The online appendix provides sources and summary statistics for all variables.

I restrict the analysis in the first instance to these variables. However, the results are robust to the inclusion of a wide variety of additional controls, including government ideology, single- versus multi-party government, veto points, spending on social policy, GDP per capita, urbanization, income tax structure, Kyoto Protocol ratification, and EU membership (see online appendix).

There are two types of problems that can arise when analyzing time-series cross-sectional data. First, the error terms may suffer from autocorrelation and/or heteroskedasticity. To correct for both I use robust standard errors clustered at the country level. The second potential problem is nonstationarity. If both the dependent and key independent variable are heavily trending upward or downward, they may be nonstationary. If so, an association between them may be spurious. An Im-Pesaran-Shin unit root test of electoral competition rejects the null hypothesis that all panels contain a unit root at the one percent level. In the case of tax rates, the evidence against the null is weaker and can only be rejected the ten 
percent level. Since both the dependent and independent variables are not nonstationary, I proceed with the analysis. Robustness tests using percent changes as the dependent variable, which does not have a unit root, further decreases concerns about nonstationary.

As final checks, I use jackknife resampling to investigate whether one country in the sample is driving the results. I find no evidence of this. I also estimate an alternative specification using logit models. The dependent variable equals 1 if the tax rate is increased and 0 otherwise. This setup assumes that all tax increases are equal in magnitude, which in practice is not valid. However, it enables a very strict test of whether competition decreases the probability of any tax increase. This alternative specification does not substantively alter the results 8

\section{Results}

\subsection{Electoral competition and gasoline taxation}

Table 2 presents the main results. The coefficients for electoral competition have a negative sign and are statistically significant. As expected, high levels of electoral competition are associated with low levels of gasoline taxation, all else equal. Specifically, a one-unit increase in electoral competition is correlated with a decrease in the tax rate of 6.24 cents per liter, relative to a sample mean of 47 cents. While the estimated impact is rather large, remember that the range of electoral competition is $0-1$. In which case, a sensible interpretation is to consider a one standard deviation increase (0.34), which is associated with a decrease of around 2.12 cents per liter.

Apart from being statistically significant, the results are substantively meaningful. Consider the case of Ireland. It has the lowest average level of electoral competition in the sample. Since the adoption of its carbon tax in 2008, the gasoline tax rate has increased annually by around 4.2 cents per liter. If competition was to suddenly increase one standard

8. See online appendix. 
deviation, we would expect this rate of increase to be cut in half. Such an impact is likely to have to increase carbon emissions.

Table 2: Electoral competition and gasoline taxation

\begin{tabular}{|c|c|c|}
\hline & $(1)$ & $(2)$ \\
\hline Electoral competition (t-1) & $\begin{array}{c}-4.777^{* *} \\
(2.173)\end{array}$ & $\begin{array}{c}-6.235^{* * *} \\
(2.177)\end{array}$ \\
\hline Green cabinet seats $(t-1)$ & & $\begin{array}{c}0.223 \\
(0.192)\end{array}$ \\
\hline Left cabinet seats $(t-1)$ & & $\begin{array}{c}0.0297 \\
(0.0194)\end{array}$ \\
\hline Environmental issue saliency $(\mathrm{t}-1)$ & & $\begin{array}{l}-0.180 \\
(0.317)\end{array}$ \\
\hline Election year & & $\begin{array}{c}-0.910^{* *} \\
(0.321)\end{array}$ \\
\hline Oil production (t-1) & & $\begin{array}{c}0.827^{* * *} \\
(0.135)\end{array}$ \\
\hline Inflation (t-1) & & $\begin{array}{l}1.143^{* *} \\
(0.485)\end{array}$ \\
\hline Budget deficit (t-1) & & $\begin{array}{c}0.107 \\
(0.229)\end{array}$ \\
\hline Debt $(\mathrm{t}-1)$ & & $\begin{array}{c}0.154^{* *} \\
(0.0665)\end{array}$ \\
\hline Nominal GDP growth (t-1) & & $\begin{array}{l}-0.468^{*} \\
(0.227)\end{array}$ \\
\hline $\mathrm{VAT}$ rate $(\mathrm{t}-1)$ & & $\begin{array}{c}0.189 \\
(0.159) \\
\end{array}$ \\
\hline Country FE & Yes & Yes \\
\hline Year FE & Yes & Yes \\
\hline $\mathrm{R}^{2}-$ within & 0.677 & 0.757 \\
\hline Countries & 20 & 20 \\
\hline$N$ & 405 & 401 \\
\hline
\end{tabular}

The results offer strong evidence that electoral competition structures the politics of fossil fuel taxation. By incentivizing governments to focus myopically on the next contest, high 
levels of competition discourage increased rates. It is parties that feel secure in office that can look past the next election to contemplate and address society's long-run challenges, even if it means increased short-term political risk.

Moreover, the evidence is consistent with country experiences. In Sweden, the Social Democrats dominated politics for most of the twentieth century, rarely receiving less than 40 percent of the vote. It was from this electorally secure position that the party adopted one of the world's first carbon taxes in 1990, applying it to gasoline and other household fuel use. In Germany, the government adopted an eco-tax in 1998, which was applied to a range of fossil fuels, including gasoline, and was set to increase annually. However, after electoral competition increased dramatically following the 2002 election, the Social Democratic-Green coalition decided against any further increases. Lastly, elevated competition in the UK since 2010 has coincided with the Treasury's decision to freeze the gasoline tax rate for ten consecutive years.

\section{$5.2 \quad$ Voters and personal costs}

The main results assume that politicians will tend to view voters as uniformly opposed to fossil fuel tax increases. Here I relax that assumption to investigate how politicians' response to rising competition is shaped by variation in their perception of voter preferences.

One heuristic used by governments to anticipate voter preferences should be costs. Similar to other taxes, voter preferences toward fossil fuel taxes should, in general, be shaped by the costs and benefits to them of such taxes (Hettich and Winer 1988). However, as mentioned, the crucial problem for the governing party is that, like other long-term policy investments, the costs and benefits of increased taxation are not temporally aligned for voters.

The governing party should expect that voter preferences for fossil fuel taxes depend primarily on the average short-term individual cost, or personal cost, that such taxes generate. For example, they should expect that SUV drivers are unlikely to prefer an increase in the gasoline tax rate, while cyclists are likely to be indifferent or even supportive. This 
reasoning is also consistent with survey research mentioned above. Furthermore, it is consistent with the logic of cost-benefit analysis, which usually describes policy costs in terms of average short-term costs to households and is often used by governments to evaluate the distributional effects, and political feasibility, of fossil fuel taxes.

The negative effect of electoral competition on tax rates should therefore be different at different levels of personal cost. When the governing party perceives the personal costs of an increase to be low, there should be less political risk in adopting it, even at high levels of competition, as the party expects voters to be relatively indifferent about rate changes. Put differently, it should be politically safe to increase taxes if such increases do not cost voters anything. However, as personal costs rise, voter preferences become tilted against tax rises. High personal costs coupled with high electoral competition should generate the strongest incentives to not increase rates, or reduce them.

A measure of politicians' perceptions of voters' personal costs presents a number of possibilities. The most straightforward is gasoline consumption per capita. The more the average voter consumes gasoline, the more a tax increase will cost them, all else equal. To be sure, consumption is endogenous to the tax rate. To reduce endogeneity, I lag consumption two years. To measure fuel consumption, I calculate average gasoline consumption (liters per capita) using data on household gasoline consumption and population $\left[{ }^{9}\right.$

I interact electoral competition with gasoline consumption to estimate the influence of competition at different levels of consumption (Table 3). The coefficient for the interaction term is negative and statistically significant. Graphing the marginal effect of a one-unit increase in competition at different levels of consumption, we see that as consumption increases the negative impact of competition also increases (Figure 3). When consumption is 500 liters per capita (near the sample average) a one standard deviation increase in competition is associated with a decrease in the tax level around 1.94 cents per liter, all else

9. Data on median gasoline consumption would be ideal, but it is unavailable for the sample of countries. The results are also robust to using an alternative measure of personal cost: expenditure on gasoline as a percentage of household income (see online appendix). 
Figure 3: Marginal effects of electoral competition at different levels of gasoline consumption

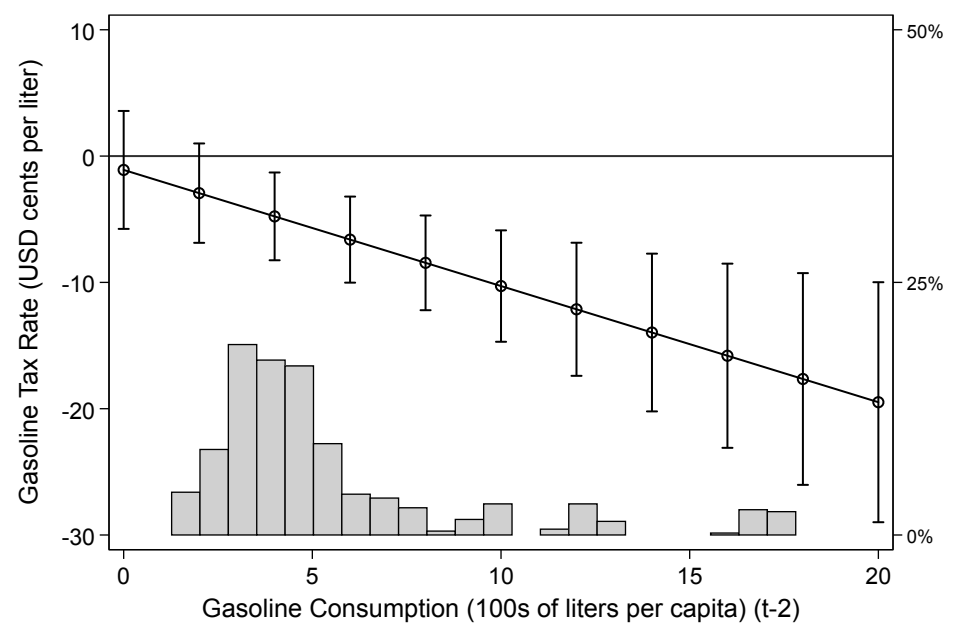

Note: Shaded bars indicate density of observations.

equal. However, as per capita consumption doubles to 1,000 liters, the same increase is now associated with a decrease of 3.5 cents. At very high levels of consumption, for example the 1,700 liters per capita average for the US, a one standard deviation increase is associated with a decrease of almost 6 cents per liter.

We also see that electoral competition has no influence on the tax rate at very low levels of fuel consumption. This should be expected. When the personal costs of a tax increase are low, electoral competition is unlikely to affect politicians' decision-making, since rate increases on goods that are not widely consumed are less likely to lose votes. Indeed, in a world where no voter consumes fossil fuels putting up tax rates would involve little political risk. It explains the high tax rates we observe in Belgium, which has one of the highest levels of electoral competition, but one of the lowest levels of gasoline consumption.

Taken together, the results provide strong evidence that government perceptions of voters' personal costs moderate the relationship between electoral competition and tax rates. They also offer two broader implications. The first is a two-way relationship between consumption of a taxed good and its tax rate. Standard economic theory predicts that tax rates affect consumption. However, the results here indicate that consumption also affects the tax rate 
Table 3: Electoral competition and personal costs

\begin{tabular}{|c|c|c|}
\hline & $(1)$ & $(2)$ \\
\hline Electoral competition (t-1) & $\begin{array}{c}0.916 \\
(2.736)\end{array}$ & $\begin{array}{l}-1.095 \\
(2.382)\end{array}$ \\
\hline Gasoline consumption per capita (t-2) & $\begin{array}{c}-3.201^{* *} \\
(1.452)\end{array}$ & $\begin{array}{l}-2.220 \\
(1.383)\end{array}$ \\
\hline Electoral comp. $(\mathrm{t}-1)^{*}$ Gasoline consump. $(\mathrm{t}-2)$ & $\begin{array}{c}-1.102^{* * *} \\
(0.365)\end{array}$ & $\begin{array}{c}-0.920^{* * *} \\
(0.309)\end{array}$ \\
\hline Green cabinet seats $(\mathrm{t}-1)$ & & $\begin{array}{c}0.234 \\
(0.168)\end{array}$ \\
\hline Left cabinet seats $(\mathrm{t}-1)$ & & $\begin{array}{c}0.0237 \\
(0.0187)\end{array}$ \\
\hline Environmental issue saliency (t-1) & & $\begin{array}{c}-0.0459 \\
(0.306)\end{array}$ \\
\hline Election year & & $\begin{array}{c}-0.833^{* *} \\
(0.353)\end{array}$ \\
\hline Oil production (t-1) & & $\begin{array}{c}0.755^{* * *} \\
(0.114)\end{array}$ \\
\hline Inflation (t-1) & & $\begin{array}{l}1.029^{* *} \\
(0.472)\end{array}$ \\
\hline Budget deficit (t-1) & & $\begin{array}{c}0.190 \\
(0.204)\end{array}$ \\
\hline Debt $(t-1)$ & & $\begin{array}{c}0.123^{*} \\
(0.0631)\end{array}$ \\
\hline Nominal GDP growth (t-1) & & $\begin{array}{c}-0.520^{* *} \\
(0.224)\end{array}$ \\
\hline VAT rate $(\mathrm{t}-1)$ & & $\begin{array}{l}0.0895 \\
(0.172)\end{array}$ \\
\hline Country FE & Yes & Yes \\
\hline Year FE & Yes & Yes \\
\hline $\mathrm{R}^{2}-$ within & 0.716 & 0.774 \\
\hline Countries & 20 & 20 \\
\hline 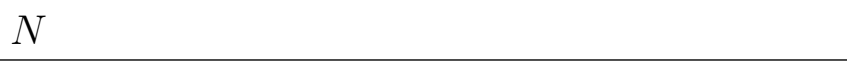 & 405 & 401 \\
\hline
\end{tabular}

by shaping politicians' perceptions of voter preferences. The general implication is that tax policy is structured by the size of the group subject to the tax, especially in the case of consumption taxes. 
Secondly, the results suggest a long-run positive feedback effect between electoral competition, fossil fuel consumption, and tax rates. Lower taxes mean lower prices, which in turn encourage higher consumption. Higher consumption should make it more difficult for politicians to increase tax rates, even at low levels of competition. As a result, there may be a "high consumption-low tax trap". Conversely, higher taxes mean higher prices, which helps to reduce consumption, and by doing so, make it easier for politicians to raise taxes in the future. This effect should generate strong path dependencies over time that push countries onto different fossil fuel taxation and consumption trajectories. Those on high tax-low consumption trajectories, such as Belgium, Italy, and Portugal, should find it more politically feasible to purge fossil fuels from the economy over time using taxation. However, for those caught in a high consumption-low tax trap, changing trajectories using pricing instruments alone will likely prove difficult, especially in times of heightened electoral competition. This dynamic helps to explain why high consumption-low tax countries such as Australia, Canada, and the US have found it so politically difficult to increase fossil fuel prices using taxation (Rabe 2010, 2018).

\subsection{Likely winners, likely losers, and government preferences}

Lastly, I explore whether behavior varies between governments that are likely to win the next election (likely winners) versus those that are likely to lose (likely losers), as well as governments of different parties. To do so, I utilize the raw loss probability data from Kayser and Lindstädt. Electoral competition is highest around middle values of loss probability and lowest at very high and very low values. Likely winners should reduce rates as their loss probability approaches 0.5. For likely losers, expectations are mixed, as described above. To model the relationship, I estimate quadratic fixed effects regressions that include loss probability and its square. 
Figure 4: Likely winners versus likely losers

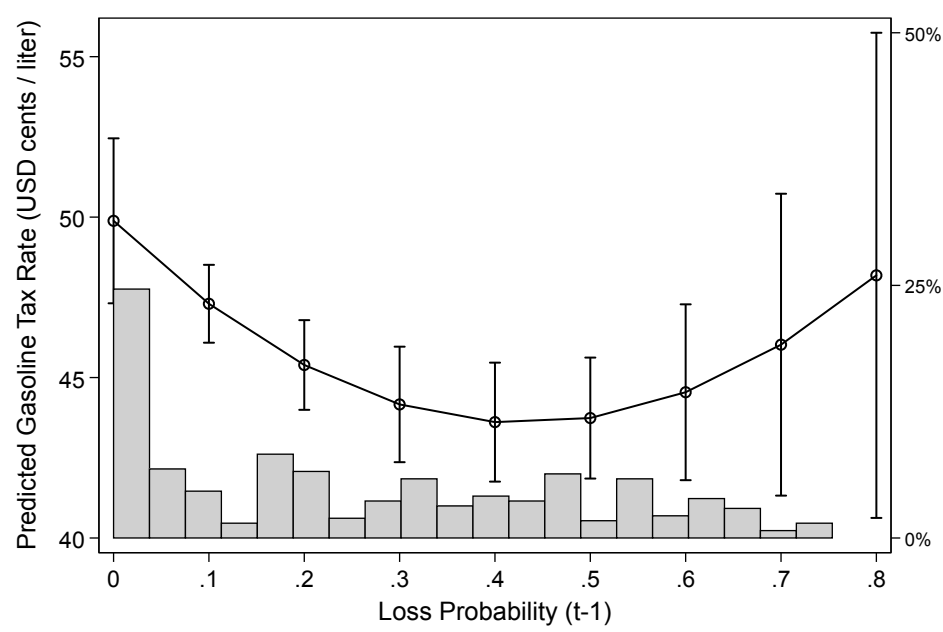

Note: Likely winners are governments with loss probability scores below 0.5 . Likely losers have scores above 0.5 . Shaded bars indicate density of observations.

The coefficient for loss probability is negative and statistically significant, while the coefficient for its square is positive and significant at the 10 percent level (Table 4 - Model 1). Plotting predicted tax levels over different values of loss probabilities, holding all other variables at their means, enables easier interpretation (Figure 4). We observe a U-shaped relationship. As expected, tax rates are lowest at middle values of loss probability where electoral competition is highest. Furthermore, there is clear evidence that likely winners put up rates as competition decreases. For likely losers, the predicted tax levels suggest that they behave similarly, putting up rates as their probability of losing increases. While the result evidences that the impact of electoral competition is symmetrical across likely winners and likely losers, the low number of observations above 0.5 and large confidence intervals prevent drawing strong conclusions.

To further analyze likely losers and to investigate the role of government preferences, I examine whether the behavior of likely winners and losers varies by partisanship using threeway interactions. It is not obvious which parties will consistently take a pro-climate position. Climate policy, and environmental policy more generally, is often a cross-cutting cleavage that does not fit neatly along a conventional left-right dimension (Mildenberger 2020). Indeed, 
some studies suggest a link between green parties and environmental performance (Jahn 2016; Jensen and Spoon 2011), left parties and the environment (Jahn 2016; Ward and Cao 2012), and left parties and consumption taxes (Beramendi and Rueda 2007). However, others do not find clear partisan effects (Aklin and Urpelainen 2013; Fankhauser, Gennaioli, and Collins 2015; Mildenberger 2020; Rafaty 2018). In the main analyses above, I find that partisanship has no independent influence on tax rates.

For simplicity, I focus on parties along two dimensions: left — right and green—non-green. Given their historical reliance on consumption taxes to fund social policy (Beramendi and Rueda 2007), I assume that left parties are more likely to prefer increased fossil fuel taxation as an instrument to mitigate climate change. Likewise, given their ideological commitment to the environment, I assume green parties will hold the strongest pro-climate preferences of any party. I use dummy variables to measure left incumbent governments and incumbent governments where greens control at least one cabinet seat. Models 2 and 3 in Table 4 present the results. For ease of interpretation, I plot the three-way interaction results graphically.

Turning first to the left - right dimension, we see that both left and right likely winner governments act in a similar way, increasing taxes as their loss probability decreases (Figure 5). However, there is suggestive evidence that their behavior diverges once they become likely losers. Left governments appear to increase tax rates as their likelihood of losing increases, while right ones further reduce them. To be sure, the difference between them is not statistically significant. Nevertheless, it may indicate that left governments are hoping to lock in their preferred policy before leaving office. This partisan divergence may help to explain the large confidence intervals in Figure 4.

The results are similar on the green-non-green dimension (Figure 6). Again, there is suggestive evidence that green governments increase rates more than non-green ones, especially when going into elections where they are likely to lose. Similar to left parties, green governments may be increasing rates when they are likely to lose in an effort to lock-in their preferred policies. However, again, there is no statistical difference in the behavior of 
Figure 5: Likely winners versus likely losers along left-right dimension

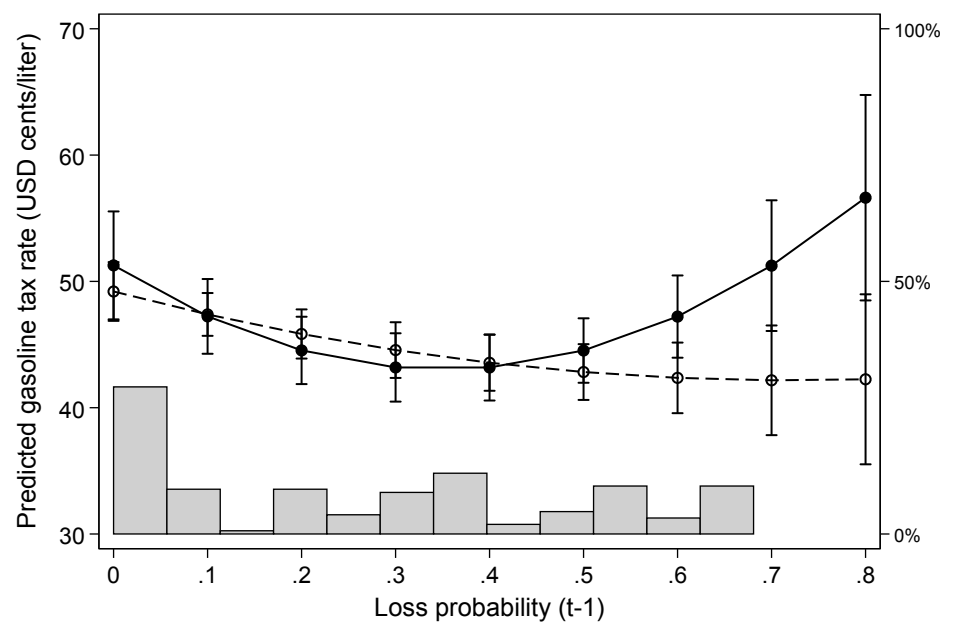

Note: The solid line represents left incumbent governments. The dotted line is non-left incumbents. Likely winners are governments with loss probability scores below 0.5. Likely losers have scores above 0.5. Shaded bars indicate density of left government observations.

green and non-green governments. The results are unchanged when using left—right and green - growth ideology scores instead of partisanship (see online appendix).

Overall, I find that likely winner governments of all parties behave in a manner consistent with my theory, increasing rates as their likelihood of winning grows. Similarly, governments of all parties facing close contests decrease them. These results support the argument that the effect of competition is causally prior to government preferences for these two categories of politicians. Amongst likely loser governments on the other hand, there is weak evidence of divergence, with left and green governments increasing rates as their likelihood of losing increases and non-left and non-green governments leaving them unchanged. More broadly, the results are consistent with the climate politics research mentioned above, which has found mixed evidence for a partisan effect. 
Figure 6: Likely winners versus likely losers along green-non-green dimension

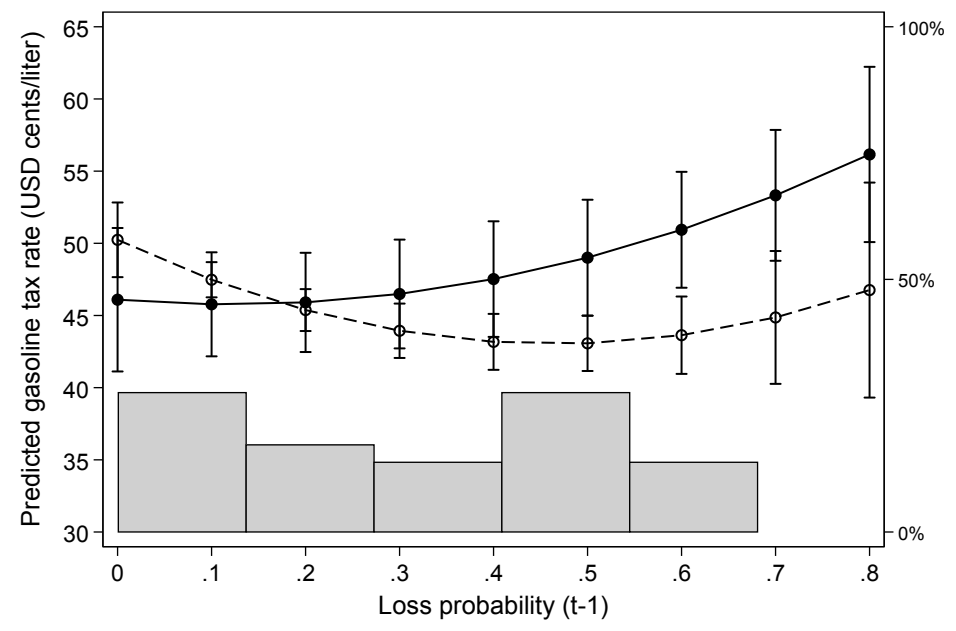

Note: The solid line represents incumbent governments that include green parties. The dotted line is non-green incumbents. Likely winners are governments with loss probability scores below 0.5. Likely losers have scores above 0.5. Shaded bars indicate density of green government observations.

\section{Conclusion}

Fossil fuel taxation presents governments with a sharp intertemporal tradeoff: increase voters' energy costs today to mitigate future climate change and promote long-run aggregate welfare; or keep costs low now, but generate greater future harm. This paper argues that how elected officials respond to this tradeoff depends in part on the electoral environment.

In times of low electoral competition, when governing parties are secure in office, they are better insulated from electoral backlash. Higher insulation should enable them to look beyond the next election to society's long-run welfare and tolerate the electoral risks of imposing costs on voters today for future benefits. However, when competition is high, governments must focus myopically on winning the next contest. Any long-term policy investment that could upset voters, such as fossil fuel taxes, is unlikely to be considered. While politically expedient, such a strategy contributes to greater future costs. In this way, electoral competition shapes governments' discount rates. When it is low, politicians place a higher value on the future benefits of policy relative to the short-term costs. But when it 
is high, politicians are likely to heavily discount future benefits.

Analyzing an original dataset of gasoline taxation, I find robust empirical support for these arguments. Across a range of model specifications, increases in electoral competition are associated with significant decreases in gasoline taxation. Moreover, I find that the negative impact of competition is moderated by politicians' perception of voter preferences. When tax increases are expected to impose large personal costs on voters, because fuel consumption is high, heightened competition generates even stronger incentives to not increase rates. The analysis suggests a long-run positive feedback effect between electoral competition, fossil fuel consumption, and fossil fuel taxation, which should generate path dependencies that push countries onto different fossil fuel consumption and taxation trajectories. For those caught in a "high consumption-low tax trap", such as the US, changing trajectories using taxation alone will likely prove difficult. Lastly, I find little evidence that government preferences are significant predictors of tax policy, suggesting that the impact of competition on intertemporal policymaking is relatively independent of partisanship and ideology.

While the evidence presented is consistent with the argument that electoral competition shapes politicians' myopia, the research design cannot entirely rule out other motivations, such as governments' concerns about the immediate cross-sectional impact of tax increases. But the claim is not that fossil fuel taxation is only a question of intertemporal policymaking. All taxes tend to be unpopular with voters. We should therefore expect all governments to be reticent about increasing them, especially those that are electorally vulnerable. However, the insight is that the relative magnitude of competition's effect should be positively correlated with when the benefits of the tax arrive. Competition should have less of an effect when benefits arrive immediately and more when their arrival is delayed.

Scholars have argued that because voters typically oppose fossil fuel taxation, politicians also oppose it. Yet this reasoning cannot explain the variation in tax rates we observe. By focusing on the role of the electoral environment, this paper provides a general theoretical 
framework that can account for the substantial diversity of tax levels within countries over time and across them. Doing so contributes to the emerging subfield of comparative climate politics (Harrison and Sundstrom 2010; Hughes and Urpelainen 2015; Lipscy forthcoming; Mildenberger 2020; Wood et al. 2019). The paper also provides a sharp test of intertemporal policy choice, contributing to broader debates in political science regarding the politics of long-term policymaking and the myopic effects of electoral competition (Alesina and Tabellini 1990; Azzimonti 2015; Boston 2016; Garrett 1993; Hübscher and Sattler 2017; Immergut and Abou-Chadi 2014, Jacobs 2011, 2016; Nordhaus 1975).

More broadly, the findings point to a causal mechanism - electoral competition - that should link macro institutions to climate policy. Politicians elected under proportional electoral rules tend to enjoy lower levels of electoral competition relative to those elected under majoritarian rules (Kayser and Lindstadt 2015). As a consequence, we should expect longrun fossil fuel taxes to be systematically higher in PR countries. This reasoning is consistent with work that highlights the key role of electoral rules in shaping climate policy outcomes, particularly regarding costs for consumers (Finnegan 2019; Lispcy forthcoming).

Finally, the findings shed light on the politics of climate policy instrument choice. In instances of low competition, we should expect governments to be more likely to directly increase consumer energy prices using taxes. However, when competition is high, such policies are unlikely to be politically feasible. Instead, politicians should be expected to use policy instruments that hide costs from voters. For example, in the case of the transport sector they should be expected to choose fuel efficiency standards (which directly impose costs on manufacturers) or subsidies for electric vehicles (funded through general revenues) over fuel tax increases. In this way, electoral competition shapes how politicians distribute the short-term costs of climate change mitigation between producers and consumers. 
Table 4: Likely winners, likely losers, and government preferences

\begin{tabular}{|c|c|c|c|}
\hline & $(1)$ & $(2)$ & $(3)$ \\
\hline Loss probability $(\mathrm{t}-1)$ & $\begin{array}{c}-29.24^{* *} \\
(11.83)\end{array}$ & $\begin{array}{l}-19.53^{*} \\
(9.955)\end{array}$ & $\begin{array}{c}-31.00^{* *} \\
(12.04)\end{array}$ \\
\hline Loss probability $^{2}(\mathrm{t}-1)$ & $\begin{array}{l}33.90^{*} \\
(17.76)\end{array}$ & $\begin{array}{c}13.55 \\
(15.13)\end{array}$ & $\begin{array}{c}33.30^{*} \\
(17.95)\end{array}$ \\
\hline Left incumbent (t-1) & & $\begin{array}{c}2.066 \\
(2.224)\end{array}$ & \\
\hline Loss probability*Left incumbent (t-1) & & $\begin{array}{c}-27.59^{* *} \\
(10.31)\end{array}$ & \\
\hline Loss probability*Loss probability*Left incumbent ( $\mathrm{t}-1)$ & & $\begin{array}{c}53.72^{* * *} \\
(18.58)\end{array}$ & \\
\hline Green incumbent $(\mathrm{t}-1)$ & & & $\begin{array}{l}-4.150 \\
(2.710)\end{array}$ \\
\hline Loss probability*Green incumbent (t-1) & & & $\begin{array}{c}25.56 \\
(17.45)\end{array}$ \\
\hline Loss probability*Loss probability*Green incumbent $(\mathrm{t}-1)$ & & & $\begin{array}{l}-10.78 \\
(25.23)\end{array}$ \\
\hline Green cabinet seats $(t-1)$ & $\begin{array}{c}0.211 \\
(0.185)\end{array}$ & $\begin{array}{c}0.224 \\
(0.200)\end{array}$ & \\
\hline Left cabinet seats $(\mathrm{t}-1)$ & $\begin{array}{c}0.0284 \\
(0.0198)\end{array}$ & & $\begin{array}{c}0.0262 \\
(0.0193)\end{array}$ \\
\hline Environmental issue attention $(\mathrm{t}-1)$ & $\begin{array}{l}-0.195 \\
(0.319)\end{array}$ & $\begin{array}{l}-0.192 \\
(0.320)\end{array}$ & $\begin{array}{l}-0.258 \\
(0.316)\end{array}$ \\
\hline Election year $(\mathrm{t}-1)$ & $\begin{array}{c}-0.984^{* * *} \\
(0.335)\end{array}$ & $\begin{array}{c}-1.016^{* * *} \\
(0.337)\end{array}$ & $\begin{array}{c}-0.963^{* *} \\
(0.339)\end{array}$ \\
\hline Oil production (t-1) & $\begin{array}{c}0.836^{* * *} \\
(0.138)\end{array}$ & $\begin{array}{c}0.777^{* * *} \\
(0.127)\end{array}$ & $\begin{array}{c}0.851^{* * *} \\
(0.139)\end{array}$ \\
\hline Inflation (t-1) & $\begin{array}{l}1.130^{* *} \\
(0.478)\end{array}$ & $\begin{array}{l}1.134^{* *} \\
(0.465)\end{array}$ & $\begin{array}{l}1.090^{* *} \\
(0.485)\end{array}$ \\
\hline Budget deficit (t-1) & $\begin{array}{l}0.0854 \\
(0.230)\end{array}$ & $\begin{array}{l}0.0625 \\
(0.253)\end{array}$ & $\begin{array}{c}0.183 \\
(0.206)\end{array}$ \\
\hline Debt (t-1) & $\begin{array}{c}0.160^{* *} \\
(0.0672)\end{array}$ & $\begin{array}{c}0.168^{* *} \\
(0.0638)\end{array}$ & $\begin{array}{c}0.145^{* *} \\
(0.0633)\end{array}$ \\
\hline Nominal GDP growth $(\mathrm{t}-1)$ & $\begin{array}{c}-0.477^{* *} \\
(0.226)\end{array}$ & $\begin{array}{l}-0.472^{*} \\
(0.230)\end{array}$ & $\begin{array}{c}-0.499^{* *} \\
(0.211)\end{array}$ \\
\hline $\operatorname{VAT}$ rate $(\mathrm{t}-1)$ & $\begin{array}{c}0.164 \\
(0.158)\end{array}$ & $\begin{array}{c}0.165 \\
(0.154)\end{array}$ & $\begin{array}{c}0.158 \\
(0.161)\end{array}$ \\
\hline Country FE & Yes & Yes & Yes \\
\hline Year FE & Yes & Yes & Yes \\
\hline $\mathrm{R}^{2}-$ within & 0.759 & 0.762 & 0.765 \\
\hline $\begin{array}{l}\text { Countries } \\
N\end{array}$ & $\begin{array}{c}20 \\
401\end{array}$ & $\begin{array}{c}20 \\
401\end{array}$ & $\begin{array}{c}20 \\
401\end{array}$ \\
\hline
\end{tabular}

Note: The dependent variable is the gasoline excise tax rate in nominal USD cents per liter. Robust standard errors in parentheses clustered at the country level. ${ }^{*} p<0.10,{ }^{* *} p<0.05,{ }^{* * *} p<0.01$. 


\section{References}

Abou-Chadi, Tarik, and Matthias Orlowski. 2016. "Moderate as Necessary: The Role of Electoral Competitiveness and Party Size in Explaining Parties' Policy Shifts." The Journal of Politics 78 (3): 868-881. doi:10.1086/685585.

Aklin, Michaël, and Johannes Urpelainen. 2013. "Political Competition, Path Dependence, and the Strategy of Sustainable Energy Transitions." American Journal of Political Science 57 (3): 643-658. doi:10.1111/ajps.12002.

Alesina, Alberto, and Guido Tabellini. 1990. "A Positive Theory of Fiscal Deficits and Government Debt." The Review of Economic Studies 57 (3): 403-414. doi:10.2307/2298021.

Andersen, Mikael Skou. 2019. "The politics of carbon taxation: how varieties of policy style matter." Environmental Politics 28 (6): 1084-1104. doi:10 . 1080/09644016 . 2019 . 1625134.

Andersson, Julius J. 2019. "Carbon Taxes and CO2 Emissions: Sweden as a Case Study." American Economic Journal: Economic Policy. doi:10.1257/pol.20170144.

Ansolabehere, Stephen, and David M. Konisky. 2014. Cheap and Clean: How Americans Think about Energy in the Age of Global Warming. MIT Press.

Azzimonti, Marina. 2015. "The dynamics of public investment under persistent electoral advantage." Review of Economic Dynamics 18 (3): 653-678. doi:10.1016/j.red.2014. 08.005 .

Bechtel, Michael M., and Kenneth F. Scheve. 2013. "Mass support for global climate agreements depends on institutional design." Proceedings of the National Academy of Sciences 110 (34): 13763-13768. doi:10.1073/pnas.1306374110.

Beramendi, Pablo, and David Rueda. 2007. "Social Democracy Constrained: Indirect Taxation in Industrialized Democracies." British Journal of Political Science 37 (04): 619641. doi:10.1017/S0007123407000348.

Berry, Frances Stokes, and William D. Berry. 1992. "Tax Innovation in the States: Capitalizing on Political Opportunity." American Journal of Political Science 36 (3): 715-742. doi: $10.2307 / 2111588$.

Beuermann, Christiane, and Tilman Santarius. 2006. "Ecological tax reform in Germany: handling two hot potatoes at the same time." Energy Policy, Social and political responses to ecological tax reform in Europe, 34 (8): 917-929. doi:10.1016/j . enpol. 2004.08 .045 .

Blais, André, and Ignacio Lago. 2009. "A general measure of district competitiveness." Electoral Studies 28 (1): 94-100. doi:10.1016/j.electstud.2008.07.007.

Boston, Jonathan. 2016. Governing for the Future: Designing Democratic Institutions for a Better Tomorrow. Bingley, UK: Emerald Group. 
Boyne, George A. 1998. "Party Competition and Local Spending Decisions." British Journal of Political Science 28 (1): 210-222.

Cao, Xun, Helen V. Milner, Aseem Prakash, and Hugh Ward. 2014. "Research Frontiers in Comparative and International Environmental Politics An Introduction." Comparative Political Studies 47 (3): 291-308. doi:10.1177/0010414013509567.

Carter, Neil, and Ben Clements. 2015. "From 'greenest government ever' to 'get rid of all the green crap': David Cameron, the Conservatives and the environment." British Politics 10 (2): 204-225. doi:10.1057/bp.2015.16

Convery, Frank, Louise Dunne, Deirdre Joyce, et al. 2014. "Ireland's Carbon Tax in the context of the Fiscal Crisis." Cyprus Economic Policy Review 8 (2): 135-143.

Cox, Gary W., Jon H. Fiva, and Daniel M. Smith. 2020. "Measuring the Competitiveness of Elections." Political Analysis 28 (2): 168-185. doi:10.1017/pan.2019.28.

Cronert, Axel, and Pär Nyman. 2020. "A general approach to measuring electoral competitiveness for parties and governments." Political Analysis.

. 2021. "Electoral Opportunism: Disentangling Myopia and Moderation." APSA Preprints. doi:10.33774/apsa-2021-s7h95.

Drews, Stefan, and Jeroen C. J. M. van den Bergh. 2015. "What explains public support for climate policies? A review of empirical and experimental studies." Climate Policy 16 (7): 855-876. doi:10.1080/14693062.2015.1058240.

Ekins, Paul, Harold Kleinman, Sarah Bell, and Andrew Venn. 2010. "Two unannounced environmental tax reforms in the UK: The fuel duty escalator and income tax in the 1990s." Ecological Economics, Special Section: Ecosystem Services Valuation in China, 69 (7): 1561-1568. doi:10.1016/j.ecolecon.2010.02.018.

Fankhauser, Samuel, Caterina Gennaioli, and Murray Collins. 2015. "The political economy of passing climate change legislation: Evidence from a survey." Global Environmental Change 35:52-61. doi:10.1016/j.gloenvcha.2015.08.008.

Finnegan, Jared J. 2019. "Low carbon for the long term: essays on the comparative political economy of climate change policy." PhD diss., London School of Economics and Political Science.

Garrett, Geoffrey. 1993. "The Politics of Structural Change Swedish Social Democracy and Thatcherism in Comparative Perspective." Comparative Political Studies 25 (4): 521547. doi:10.1177/0010414093025004004

Geschwind, Carl-Henry. 2017. A Comparative History of Motor Fuels Taxation, 1909-2009: Why Gasoline Is Cheap and Petrol Is Dear. London: Lexington Books.

Harrison, Kathryn. 2012. "A Tale of Two Taxes: The Fate of Environmental Tax Reform in Canada." Review of Policy Research 29 (3): 383-407. doi:10.1111/j.1541-1338.2012. 00565.x. 
Harrison, Kathryn, and Lisa McIntosh Sundstrom. 2010. Global Commons, Domestic Decisions: The Comparative Politics of Climate Change. Cambridge, MA: MIT Press.

Hettich, Walter, and Stanley L. Winer. 1988. "Economic and Political Foundations of Tax Structure." The American Economic Review 78 (4): 701-712.

High-Level Commission on Carbon Prices. 2017. Report of the High-Level Commission on Carbon Prices. Technical report. Washington, D.C.: World Bank.

Hübscher, Evelyne, and Thomas Sattler. 2017. "Fiscal consolidation under electoral risk." European Journal of Political Research 56 (1): 151-168. doi:10.1111/1475-6765.12171.

Hughes, Llewelyn, and Johannes Urpelainen. 2015. "Interests, institutions, and climate policy: Explaining the choice of policy instruments for the energy sector." Environmental Science \&f Policy 54:52-63. doi:10.1016/j.envsci.2015.06.014.

Immergut, Ellen M., and Tarik Abou-Chadi. 2014. "How electoral vulnerability affects pension politics: Introducing a concept, measure and empirical application." European Journal of Political Research 53 (2): 269-287. doi:10.1111/1475-6765.12037.

Jacobs, Alan M. 2011. Governing for the Long Term: Democracy and the Politics of Investment. Cambridge: Cambridge University Press.

— 2016. "Policy Making for the Long Term in Advanced Democracies." Annual Review of Political Science 19 (1): 433-454. doi:10.1146/annurev-polisci-110813-034103.

Jacobs, Alan M., and J. Scott Matthews. 2012. "Why Do Citizens Discount the Future? Public Opinion and the Timing of Policy Consequences." British Journal of Political Science 42 (4): 903-935. doi:10.1017/S0007123412000117.

Jagers, Sverker C., and Henrik Hammar. 2009. "Environmental taxation for good and for bad: the efficiency and legitimacy of Sweden's carbon tax." Environmental Politics 18 (2): 218-237. doi:10.1080/09644010802682601.

Jahn, Detlef. 2016. The Politics of Environmental Performance: Institutions and Preferences in Industrialized Democracies. Cambridge: Cambridge University Press.

Jensen, Christian B., and Jae-Jae Spoon. 2011. "Testing the 'Party Matters' Thesis: Explaining Progress towards Kyoto Protocol Targets." Political Studies 59 (1): 99-115. doi:10.1111/j.1467-9248.2010.00852.x.

Kahneman, Daniel, Jack L. Knetsch, and Richard H. Thaler. 1991. "Anomalies: The Endowment Effect, Loss Aversion, and Status Quo Bias." Journal of Economic Perspectives 5 (1): 193-206. doi:10.1257/jep.5.1.193.

Kasa, Sjur. 2000. "Policy networks as barriers to green tax reform: The case of CO2-taxes in Norway." Environmental Politics 9 (4): 104-122. doi:10.1080/09644010008414553.

Kayser, Mark Andreas, and René Lindstädt. 2015. "A Cross-National Measure of Electoral Competitiveness." Political Analysis 23 (2): 242-253. doi:10.1093/pan/mpv001. 
Keohane, Robert O. 2015. "The global politics of climate change: Challenge for political science." PS: Political Science \& Politics 48 (01): 19-26.

Kone, Susan L., and Richard F. Winters. 1993. "Taxes and Voting: Electoral Retribution in the American States." The Journal of Politics 55 (1): 22-40. doi:10.2307/2132226.

Levi, Margaret. 1989. Of Rule and Revenue. Berkeley, CA: University of California Press.

Li, Shanjun, Joshua Linn, and Erich Muehlegger. 2014. "Gasoline Taxes and Consumer Behavior." American Economic Journal: Economic Policy 6 (4): 302-342. doi:10.1257/ pol.6.4.302.

Lipscy, Phillip Y. Forthcoming. The Institutional Politics of Energy and Climate Change. Book Manuscript. Stanford University, Stanford CA.

Meckling, Jonas, and Bentley B. Allan. 2020. "The evolution of ideas in global climate policy." Nature Climate Change 10 (5): 434-438. doi:10.1038/s41558-020-0739-7.

Mildenberger, Matto. 2020. Carbon Captured: How Business and Labor Control Climate Politics. Cambridge, MA: MIT Press.

Nordhaus, William D. 1975. "The Political Business Cycle." The Review of Economic Studies 42 (2): 169-190. doi:10.2307/2296528.

. 1977. "Economic Growth and Climate: The Carbon Dioxide Problem." The American Economic Review 67 (1): 341-346.

OECD. 2016. Effective Carbon Rates: Pricing CO2 through Taxes and Emissions Trading Systems. Technical report. Paris: Organisation for Economic Co-operation and Development.

Rabe, Barry G. 2010. "The Aversion to Direct Cost Imposition: Selecting Climate Policy Tools in the United States." Governance 23 (4): 583-608. doi:10.1111/j.1468-0491. 2010.01499.x.

- 2018. Can We Price Carbon? Cambridge, MA: MIT Press.

Rafaty, Ryan. 2018. "Perceptions of Corruption, Political Distrust, and the Weakening of Climate Policy." Global Environmental Politics 18 (3): 106-129. doi:10.1162/glep_a_ 00471 .

Ross, Michael L., Chad Hazlett, and Paasha Mahdavi. 2017. "Global progress and backsliding on gasoline taxes and subsidies." Nature Energy 2 (1): 1-6. doi:10.1038/nenergy . 2016. 201.

Schultz, Kenneth A. 1995. "The Politics of the Political Business Cycle." British Journal of Political Science 25 (1): 79-99.

Sheffer, Lior, Peter John Loewen, Stuart Soroka, Stefaan Walgrave, and Tamir Sheafer. 2017. "Nonrepresentative Representatives: An Experimental Study of the Decision Making of Elected Politicians." American Political Science Review: 1-20. doi:10.1017/S00030554 17000569 . 
Shwom, Rachael, David Bidwell, Amy Dan, and Thomas Dietz. 2010. "Understanding U.S. public support for domestic climate change policies." Global Environmental Change, Governance, Complexity and Resilience, 20 (3): 472-482. doi:10.1016/j . gloenvcha. 2010.02 .003 .

Sterner, Thomas. 2007. "Fuel taxes: An important instrument for climate policy." Energy Policy 35 (6): 3194-3202. doi:10.1016/j.enpol.2006.10.025.

Stokes, Leah C. 2016. "Electoral Backlash against Climate Policy: A Natural Experiment on Retrospective Voting and Local Resistance to Public Policy." American Journal of Political Science 60 (4): 958-974. doi:10.1111/ajps.12220.

Strom, Kaare. 1990. "A Behavioral Theory of Competitive Political Parties." American Journal of Political Science 34 (2): 565-598. doi:10.2307/2111461.

U.S. Energy Information Administration. 2020. Carbon Dioxide Emissions from Energy Consumption by Source.

Ward, Hugh, and Xun Cao. 2012. "Domestic and International Influences on Green Taxation." Comparative Political Studies 45 (9): 1075-1103. doi:10.1177/001041401143400 7.

Wood, Geoffrey, Jared J. Finnegan, Maria L. Allen, Matthew M. C. Allen, Douglas Cumming, Sofia Johan, Manuel Nicklich, Takahiro Endo, Sijeong Lim, and Seiki Tanaka. 2019. "The comparative institutional analysis of energy transitions." Socio-Economic Review. doi:10.1093/ser/mwz026. 
Online Appendix 


\section{Table of contents}

Carbon taxes and gasoline

2

Data sources for excise tax rates on regular household gasoline

3

Summary statistics and data sources

4

Validating new measure of electoral competition

7

Robustness tests

9 
Table A1. Carbon taxes and gasoline

\begin{tabular}{l|c|c}
\hline \multicolumn{1}{c|}{ Country } & $\begin{array}{c}\text { Year of carbon } \\
\text { tax adoption }\end{array}$ & $\begin{array}{c}\text { Applied directly to } \\
\text { gasoline as an } \\
\text { excise tax? }\end{array}$ \\
\hline Australia & $2011^{\mathrm{a}}$ & No \\
Canada & 2018 & Yes \\
Denmark & 1992 & Yes \\
Finland & 1990 & Yes \\
France & 2014 & Yes \\
Germany & $1999^{\mathrm{b}}$ & Yes \\
Ireland & 2009 & Yes \\
Japan & 2012 & Yes \\
Netherlands & 1990 & Yes \\
Norway & 1991 & Yes \\
Portugal & 2014 & Yes \\
Sweden & 1991 & Yes \\
United Kingdom & $2001^{\mathrm{c}}$ & No \\
\hline
\end{tabular}

Notes: ${ }^{a}$ The Carbon Pricing Mechanism was repealed in 2014.

b Refers to Germany's "eco-tax".

c Refers to the UK's Climate Change Levy. 
Table A2. Data sources for excise tax rates on regular household gasoline

\begin{tabular}{l|l}
\hline \multicolumn{1}{c|}{ Country } & \multicolumn{1}{c}{ Data source(s) } \\
\hline Australia & IEA (2016)'; James (1996) \\
Austria & IEA (2016) \\
Belgium & IEA (2016) \\
Canada & IEA (2016); International Fuel Tax Agreement \\
Denmark & IEA (2016); Statistics Denmark \\
Finland & IEA (2016) \\
France & IEA (2016) \\
Germany & IEA (2016); German Federal Ministry of Finance \\
Greece & IEA (2016) \\
Ireland & IEA (2016); Department of Finance \\
Italy & IEA (2016) \\
Japan & IEA (2016) \\
Netherlands & IEA (2016) \\
New Zealand & IEA (2016); Ministry of Business, Innovation and Employment \\
Norway & IEA (2016) \\
Portugal & IEA (2016) \\
Spain & IEA (2016) \\
Sweden & IEA (2016); Swedish Petroleum and Biofuels Institute (SPBI) \\
UK & IEA (2016); Institute for Fiscal Studies \\
USA & IEA (2016); US Federal Highway Administration \\
\hline
\end{tabular}

\footnotetext{
${ }^{1}$ International Energy Agency (IEA). 2016. "Energy Prices and Taxes: Country Notes.” Paris: International Energy Agency.

2 James, Denis. 1996. "'Beer and Cigs Up!': A Recent History of Excise in Australia." Australia Parliamentary Research Service, Background Paper No. 5 1995-1996.
} 
Table A1. Summary statistics and data sources

\begin{tabular}{|c|c|c|c|c|c|c|}
\hline Variable & Source & Obs. & Mean & Std. Dev. & Min & $\operatorname{Max}$ \\
\hline $\begin{array}{l}\text { Tax rate on } \\
\text { household gasoline } \\
\text { (nominal US cents } \\
\text { PPP per litre) }\end{array}$ & See Table A2 & 512 & 47.23 & 22.11 & 2.38 & 108.94 \\
\hline $\begin{array}{l}\text { Percent change from } \\
\text { previous year in } \\
\text { excise tax rate on } \\
\text { household gasoline } \\
\text { (based on national } \\
\text { currency rates) }\end{array}$ & See Table A2 & 505 & 3.45 & 9.86 & -44.44 & 80.00 \\
\hline Loss probability & $\begin{array}{l}\text { Kayser and } \\
\text { Lindstädt } \\
(2015)^{3} \\
\end{array}$ & 393 & 0.26 & 0.22 & 0.00 & 0.75 \\
\hline Electoral competition & $\begin{array}{l}\text { Author's } \\
\text { calculations } \\
\text { based on data } \\
\text { from Kayser } \\
\text { and Lindstädt } \\
(2015)\end{array}$ & 393 & 0.45 & 0.34 & 0.00 & 0.99 \\
\hline $\begin{array}{l}\text { Gasoline } \\
\text { consumption }(100 \text { s of } \\
\text { litres per capita) }\end{array}$ & $\begin{array}{l}\text { IEA (2016); } \\
\text { OECD } \\
(2018 \mathrm{a})^{4}\end{array}$ & 520 & 5.40 & 3.63 & 1.34 & 17.81 \\
\hline $\begin{array}{l}\text { Expenditure on } \\
\text { gasoline ( } \% \text { of } \\
\text { average income spent } \\
\text { on gasoline) }\end{array}$ & $\begin{array}{l}\text { IEA (2016); } \\
\text { OECD } \\
(2018 b)^{5}\end{array}$ & 472 & 0.01 & 0.00 & 0.00 & 0.03 \\
\hline $\begin{array}{l}\text { Green cabinet seats } \\
\text { (\% of cabinet seats } \\
\text { held by green parties) }\end{array}$ & $\begin{array}{l}\text { Author's } \\
\text { calculations } \\
\text { based on } \\
\text { Armingeon et } \\
\text { al. }(2016 b)^{6}\end{array}$ & 520 & 0.71 & 2.81 & 0.00 & 18.75 \\
\hline
\end{tabular}

${ }^{3}$ Kayser, Mark Andreas, and René Lindstädt. 2015. "A Cross-National Measure of Electoral Competitiveness." Political Analysis 23 (2): 242-53. https://doi.org/10.1093/pan/mpv001

4 Organisation for Economic Cooperation and Development (OECD). 2018a. "Demographic References."

Paris: Organisation for Economic Cooperation and Development.

${ }^{5}$ Organisation for Economic Cooperation and Development (OECD). 2018b. "Gross domestic product (GDP): GDP per head, US \$, Current prices, Current PPPs.” Paris: Organisation for Economic Cooperation and Development.

${ }^{6}$ Armingeon, Klaus, Christian Isler, David Wesisstanner and Laura Knopfel. 2016b. Supplement to the Comparative Political Data Set - Government Composition 1960-2013. Bern: Institute of Political Science, University of Berne. 


\begin{tabular}{|c|c|c|c|c|c|c|}
\hline $\begin{array}{l}\text { Left cabinet seats }(\% \\
\text { of cabinet seats held } \\
\text { by non-green left } \\
\text { parties) }\end{array}$ & $\begin{array}{l}\text { Armingeon et } \\
\text { al. }(2016 a)^{7}\end{array}$ & 520 & 35.13 & 38.61 & 0.00 & 100.00 \\
\hline $\begin{array}{l}\text { Environmental } \\
\text { saliency (sum of } \\
\text { per501 across all } \\
\text { parties divided by } \\
\text { number of parties) }\end{array}$ & $\begin{array}{l}\text { Volkens et al. } \\
(2015)^{8}\end{array}$ & 513 & 6.27 & 3.41 & 0.20 & 18.33 \\
\hline Election year & $\begin{array}{l}\text { Based on } \\
\text { Armingeon et } \\
\text { al. (2016a) }\end{array}$ & 520 & 0.28 & 0.45 & 0.00 & 1.00 \\
\hline $\begin{array}{l}\text { Budget deficit } \\
\text { (Annual deficit as \% } \\
\text { of GDP) }\end{array}$ & $\begin{array}{l}\text { Armingeon et } \\
\text { al. (2016a) }\end{array}$ & 520 & 2.49 & 4.86 & -18.70 & 32.55 \\
\hline $\begin{array}{l}\text { Government debt } \\
\text { (Gross general } \\
\text { government debt as } \\
\% \text { of GDP) }\end{array}$ & $\begin{array}{l}\text { Armingeon et } \\
\text { al. (2016a) }\end{array}$ & 520 & 73.42 & 34.55 & 16.10 & 221.47 \\
\hline $\begin{array}{l}\text { Inflation (Annual } \\
\text { growth rate of CPI) }\end{array}$ & $\begin{array}{l}\text { Armingeon et } \\
\text { al. (2016a) }\end{array}$ & 520 & 2.74 & 2.42 & -4.48 & 20.43 \\
\hline $\begin{array}{l}\text { Oil production } \\
\text { (Domestic oil } \\
\text { production - tonnes } \\
\text { per capita) }\end{array}$ & IEA $(2018)^{9}$ & 520 & 1.77 & 5.75 & 0.00 & 35.08 \\
\hline $\begin{array}{l}\text { GDP growth (Annual } \\
\text { growth rate of } \\
\text { nominal GDP per } \\
\text { capita) }\end{array}$ & $\begin{array}{l}\text { OECD } \\
(2018 b)\end{array}$ & 520 & 4.93 & 4.14 & -9.42 & 23.50 \\
\hline $\begin{array}{l}\text { VAT on gasoline } \\
\text { (Value added tax rate } \\
\text { on gasoline }-\% \text { ) }\end{array}$ & IEA (2016) & 516 & 16.13 & 7.77 & 0.00 & 36.00 \\
\hline $\begin{array}{l}\text { GDP per capita } \\
\text { (Nominal }-10,000 \\
\text { USD PPP) }\end{array}$ & $\begin{array}{l}\text { OECD } \\
(2018 b)\end{array}$ & 520 & 2.84 & 1.01 & 0.93 & 6.68 \\
\hline
\end{tabular}

7 Armingeon, Klaus, Christian Isler, Laura Knopfel, David Weisstanner and Sarah Engler. 2016a. Comparative Political Data Set 1960-2013. Bern: Institute of Political Science, University of Berne.

${ }^{8}$ Volkens, Andrea, Pola Lehmann, Theres Matthieß, Nicolas Merz, Sven Regel, and Annika Werner. 2015.

“The Manifesto Data Collection. Manifesto Project (MRG /CMP / MARPOR).” Version 2015a. Berlin:

Wissenschaftszentrum Berlin für Sozialforschung (WZB).

${ }^{9}$ International Energy Agency (IEA). 2018. “Oil Statistics”. Paris: International Energy Agency. 


\begin{tabular}{|c|c|c|c|c|c|c|}
\hline $\begin{array}{l}\text { Green vs growth } \\
\text { (government ideology } \\
\text { score) }\end{array}$ & Jahn $(2016)^{10}$ & 520 & 2.89 & 5.66 & -15.88 & 23.43 \\
\hline $\begin{array}{l}\text { Left vs right } \\
\text { (government ideology } \\
\text { score) }\end{array}$ & Jahn (2016) & 520 & 2.16 & 4.90 & -12.58 & 22.97 \\
\hline $\begin{array}{l}\text { Single-party gov } \\
\text { (Government in } \\
\text { comprised of one } \\
\text { party) }\end{array}$ & $\begin{array}{l}\text { Based on } \\
\text { Armingeon et } \\
\text { al. (2016a) }\end{array}$ & 514 & 0.41 & 0.49 & 0.00 & 1.00 \\
\hline $\begin{array}{l}\text { Political constraints } \\
\text { (POLCONIII) }\end{array}$ & $\begin{array}{l}\text { Henisz } \\
(2002)^{11}\end{array}$ & 520 & 0.48 & 0.09 & 0.21 & 0.72 \\
\hline $\begin{array}{l}\text { Social expenditures } \\
\text { (Total public and } \\
\text { mandatory private } \\
\text { social expenditure as } \\
\% \text { of GDP) }\end{array}$ & $\begin{array}{l}\text { Armingeon et } \\
\text { al. (2016a) }\end{array}$ & 482 & 22.29 & 5.06 & 10.92 & 36.01 \\
\hline $\begin{array}{l}\text { Urbanization (\% of } \\
\text { population living in } \\
\text { urban areas) }\end{array}$ & $\begin{array}{l}\text { World Bank } \\
(2018)^{12}\end{array}$ & 520 & 77.11 & 9.91 & 46.87 & 97.78 \\
\hline $\begin{array}{l}\text { Income tax structure } \\
\text { (Taxes on individual } \\
\text { income as a } \% \text { of } \\
\text { total taxation) }\end{array}$ & $\begin{array}{l}\text { OECD } \\
(2018 c)^{13}\end{array}$ & 519 & 28.69 & 10.08 & 9.70 & 56.00 \\
\hline EU membership & $\begin{array}{l}\text { Armingeon et } \\
\text { al. (2016a) }\end{array}$ & 520 & 0.66 & 0.47 & 0.00 & 1.00 \\
\hline $\begin{array}{l}\text { Kyoto Protocol } \\
\text { ratification }\end{array}$ & $\begin{array}{l}\text { UNFCCC } \\
(2009)^{14} \\
\end{array}$ & 520 & 0.42 & 0.49 & 0.00 & 1.00 \\
\hline
\end{tabular}

${ }^{10}$ Jahn, Detlef. 2016. The Politics of Environmental Performance: Institutions and Preferences in Industrialized Democracies. Cambridge: Cambridge University Press.

${ }^{11}$ Henisz, Witold J. 2002. "The Institutional Environment for Infrastructure Investment." Industrial and Corporate Change 11 (2): 355-89. https://doi.org/10.1093/icc/11.2.355.

12 World Bank. 2018. "Databank: Urban population (\% of total)." Washington, DC: World Bank. Accessed March 13, 2018. https://data.worldbank.org/indicator/sp.urb.totl.in.zs

13 Organisation for Economic Cooperation and Development (OECD). 2018c. "Revenue Statistics." Paris: Organisation for Economic Cooperation and Development.

${ }^{14}$ United Nations Framework Convention on Climate Change (UNFCCC). 2009. "Kyoto Protocol: Status of Ratification".

https://unfccc.int/files/kyoto_protocol/status_of_ratification/application/pdf/kp_ratification.pdf 


\section{Validating new measure of electoral competition}

The measure of electoral competition assumes that loss probabilities that are equidistant from 0.5 generate the same incentives for the governing party. For example, parties that have a low probability of losing their seats plurality at the next election ("likely winners" with a loss probability of 0.25 ) and those from parties that have a high probability of doing so ("likely losers" with a loss probability of 0.75 ) will behave similarly. Both therefore receive the same score after the variable is transformed (a score of 0.5 ).

To test this, I generate a dummy variable that equals 1 when a party's loss probability is less than 0.5 . These parties can be considered "likely winners" since they have a high probability of winning the next election. I then estimate a fixed effects model and interact this dummy with my measure of electoral competition and include the same controls from the main analysis. If the interaction is not statistically significant it would indicate that there is no statistical difference between the behaviour of likely winners and likely losers at different levels of electoral competition. Table A3 provides the results. The coefficient for the interaction term is not statistically different from zero. Graphing the predictive margins, we see that the confidence intervals overlap, indicating no statistical difference in behaviour between the two groups at different levels of competition (Figure A2). I take this as evidence that the assumption that likely winners and likely losers tend to behave similarly is plausible.

Figure A2. Likely winners vs. likely losers

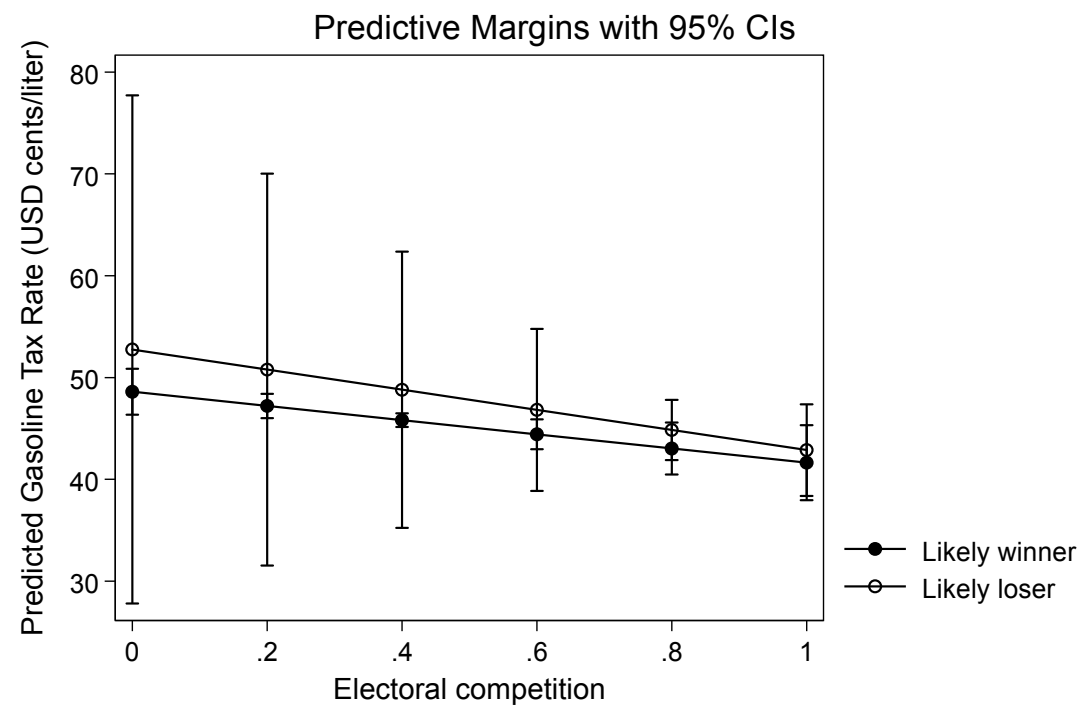


Table A3. Validating new measure of electoral competition

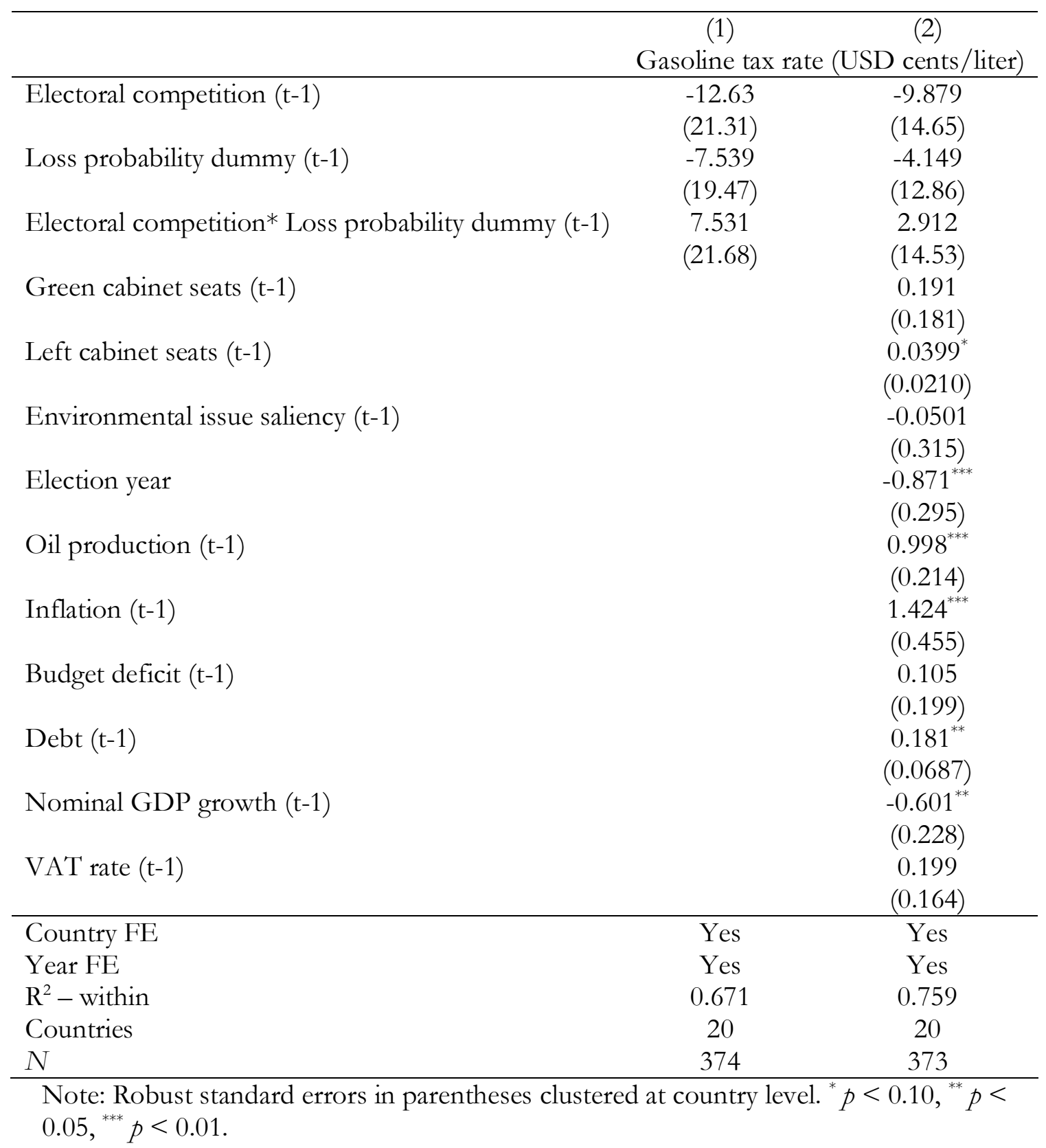




\section{$\underline{\text { Robustness tests }}$}

I subject my results to a wide variety of robustness tests (Tables A4-A6):

- Jackknife resampling (Table A4): It could be the case that one country is driving the results. To test this I re-estimate the main results using jackknife resampling, which drops each country from the dataset, calculates the estimates, and then calculates the average across all of these estimates. The results indicate that my main results are not driven by any single country in the sample. However, the results for the interactions terms suggest that the moderating influence of gasoline consumption may be driven by one, or a small handful, of countries.

- Alternative lag structure (Table A4): I re-estimate the main results using a two-year lag structure. A two-year lag between the adoption and implementation of a tax increase is also theoretically plausible. Furthermore, this lag structure has been used in previous studies (Goel and Nelson 1999). Using this structure does not alter the results.

- Restricted sample (Table A5): My main results estimate the effect of electoral competition from the perspective of the plurality party, which is usually, but not always, the prime minister's party. To demonstrate that the relationship holds for a restricted sample of times when the plurality party is also the PM's party, I re-estimate the main results using electoral competition scores for the PM's party. The results do not substantively differ from the main results.

- Additional controls (Table A5): I include a wide variety of additional controls to further rule out possibilities of omitted variable bias:

- To control for differences in income over time, which may make voters more willing to pay higher fossil fuel taxes, I include nominal GDP per capita.

- To control for government ideology (in addition to partisanship) I use party scores for left vs right and green vs growth from Jahn (2016). The latter should be a good measure of the "greenness" of party's policy preferences.

- Coalition governments may find it easier than single-party ones to increase tax rates if multi-party governments make it more difficult for voters to assign responsibility and blame to specific parties. To control for this I include a dummy for single-party government.

- It may be that government politicians are simply increasing tax rates when they face fewer veto players. To control for this, I include a commonly used measure of political constraints from Henisz (2002).

- If governments use new revenues to fund spending on public goods, the temporal lag from the perspective of voters between the costs and benefits of tax increases may be reduced, making voters more amenable to such increases. Knowing this, 
governments may be more willing to increase rates. To control for this I include a measure of government social expenditure.

- The cost of a tax increase to voters could also depend on the availability of other transportation options. When other options are readily available, such as walking, cycling, or using public transport, politicians may predict that an increase in the gasoline tax will be less risky. Since no perfect measure exists for this, I use the proportion of the population living in urban areas. The assumption is that voters in urban areas will have more readily available transport alternatives that those living in rural areas.

- Governments may simultaneously increase taxes on fossil fuels and decrease other taxes, particularly on income (a process referred to as environmental tax reform). Similar to changes in social expenditure, this may bring immediate benefits to voters and thus make it more politically feasible to increase fossil fuel taxes. To control for this I include income tax revenue as a percentage of total taxation.

- To control for the influence of the European Union I add a dummy for EU membership, as some countries became members during the sample period. In 2003 the EU issued the Energy Tax Directive, which set a minimum gasoline tax rate for all member states of 0.359 Euros/litre; though this would have had little effect for my sample. All EU countries in my sample apart from Greece had a tax rate higher than this in 2003.

- The Kyoto Protocol, adopted in 1997 by developed economies, constitutes the only legally-binding international climate change treaty. Countries ratified the agreements in different years following 1997, and some, like the US, never ratified it at all. I include a dummy for ratification of the Kyoto Protocol, since it may have compelled otherwise reluctant governments to increase fossil fuel taxation in an effort to comply.

Including these additional controls does not substantively change the results. Apart from Kyoto Protocol ratification, none of the additional coefficients are statistically significant at conventional levels. Comparing the $\mathrm{R}^{2}$ values of the models with additional controls to the main results indicates that the expanded models fit the data little better than the parsimonious models.

- Alternative specification (Table A6): To ensure that the results are not dependent on model specification, I estimate a logit model with country and year fixed effects as an alternative specification. The dependent variable equals 1 if the tax rate was increased and 0 otherwise. This is the most conservative setup since it assumes that the politics of all tax increases are equal, which in practice is not valid. For example, a large increase should be much more politically risky than a small one. However, it enables a very strict test of whether competition decreases the probability of any tax increase. I find evidence of this. A one-unit increase in electoral competition decreases the odds of a tax increase by around $60 \%$, all else equal. 
- Alternative measure of personal costs (Table A6): The results in the article use gasoline consumption per capita as a proxy for personal costs. To ensure the robustness of the results, I construct and test an alternative measure of personal costs: expenditure on gasoline as a percentage of household income. I construct this variable by multiplying gasoline consumption per capita by the pre-tax price per liter of gasoline and then dividing the product by nominal GDP per capita (Equation 1). I then re-estimate the models using this measure instead of gasoline consumption per capita. Using this alternative measure does not substantively alter the results.

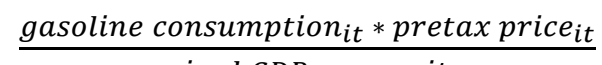

- Alternative Dependent Variable (Table A6): To ensure that the results are not dependent on measurement of the dependent variable, I generate an alternative one: annual percent changes in tax rates. To do so, I divide the first difference of the national currency tax rate by the rate in the previous year $\left(\Delta \operatorname{tax}\right.$ rate $_{i, t} / \operatorname{tax}$ rate $\left._{i, t-1}\right)$. This measures the growth rate of gasoline taxation. The benefit is that it accurately captures changes in rates and therefore political decision-making. The downside is that it does not precisely capture the magnitude of those changes. Percent changes are higher for countries with low rates in the previous year and lower for countries with high rates. To mitigate measurement error, I include the lagged tax rate level to control for the past level of taxation from which changes are made. The results are largely unchanged. 
Table A4. Robustness tests (1)

\begin{tabular}{|c|c|c|c|c|c|c|c|c|c|c|}
\hline & \multicolumn{5}{|c|}{ Jackknife resampling } & \multicolumn{5}{|c|}{ Two-year lag } \\
\hline & (1) & (2) & (3) & (4) & (5) & (6) & $(7)$ & (8) & (9) & $(10)$ \\
\hline & \multicolumn{10}{|c|}{ Gasoline tax rate (USD cents/liter) } \\
\hline Electoral competition (t-1) & $\begin{array}{l}-6.235^{* *} \\
(2.528)\end{array}$ & $\begin{array}{l}-1.095 \\
(4.000)\end{array}$ & & & & $\begin{array}{l}-6.299^{* *} \\
(2.320)\end{array}$ & $\begin{array}{c}0.631 \\
(2.255)\end{array}$ & & & \\
\hline Electoral comp. $(\mathrm{t}-1) *$ Gasoline con. $(\mathrm{t}-2)$ & & $\begin{array}{l}-0.920 \\
(0.752)\end{array}$ & & & & & $\begin{array}{c}-1.222^{* * *} \\
(0.283)\end{array}$ & & & \\
\hline Loss probability (t-1) & & & $\begin{array}{l}-29.24^{*} \\
(14.58)\end{array}$ & $\begin{array}{l}-19.53 \\
(12.48)\end{array}$ & $\begin{array}{c}-31.00^{* *} \\
(14.62)\end{array}$ & & & $\begin{array}{c}-26.65^{* *} \\
(11.42)\end{array}$ & $\begin{array}{l}-8.978 \\
(9.390)\end{array}$ & $\begin{array}{c}-27.44^{* *} \\
(11.92)\end{array}$ \\
\hline Loss probability ${ }^{2}(\mathrm{t}-1)$ & & & $\begin{array}{c}33.90 \\
(22.65)\end{array}$ & $\begin{array}{c}13.55 \\
(19.74)\end{array}$ & $\begin{array}{l}33.30 \\
(22.03)\end{array}$ & & & $\begin{array}{c}28.67 \\
(16.81)\end{array}$ & $\begin{array}{l}-1.567 \\
(14.63)\end{array}$ & $\begin{array}{c}27.25 \\
(17.40)\end{array}$ \\
\hline Loss prob.*Left inc. $(\mathrm{t}-1)$ & & & & $\begin{array}{l}-27.59^{*} \\
(14.46)\end{array}$ & & & & & $\begin{array}{c}-48.66^{* * *} \\
(13.14)\end{array}$ & \\
\hline Loss prob. $*$ Loss prob. $*$ Left inc. $(\mathrm{t}-1)$ & & & & $\begin{array}{l}53.72^{*} \\
(27.35)\end{array}$ & & & & & $\begin{array}{c}79.70^{* * *} \\
(20.16)\end{array}$ & \\
\hline Loss prob.*Green inc. $(\mathrm{t}-1)$ & & & & & $\begin{array}{c}25.56 \\
(38.35)\end{array}$ & & & & & $\begin{array}{l}20.23 \\
(20.81)\end{array}$ \\
\hline Loss prob. $*$ Loss prob. $*$ Green inc. $(\mathrm{t}-1)$ & & & & & $\begin{array}{l}-10.78 \\
(62.18)\end{array}$ & & & & & $\begin{array}{l}-5.181 \\
(28.72)\end{array}$ \\
\hline Gasoline consumption ( $\mathrm{t}-2)$ & & $\begin{array}{l}-2.220 \\
(2.144)\end{array}$ & & & & & $\begin{array}{l}-0.659 \\
(1.721)\end{array}$ & & & \\
\hline Left incumbent (t-1) & & & & $\begin{array}{c}2.066 \\
(2.617)\end{array}$ & & & & & $\begin{array}{l}4.664^{* *} \\
(2.171)\end{array}$ & \\
\hline Green incumbent $(t-1)$ & & & & & $\begin{array}{l}-4.150 \\
(5.507)\end{array}$ & & & & & $\begin{array}{l}-3.984 \\
(3.277)\end{array}$ \\
\hline Green cabinet seats $(\mathrm{t}-1)$ & $\begin{array}{c}0.223 \\
(0.295)\end{array}$ & $\begin{array}{c}0.234 \\
(0.232)\end{array}$ & $\begin{array}{c}0.211 \\
(0.308)\end{array}$ & $\begin{array}{c}0.224 \\
(0.329)\end{array}$ & & $\begin{array}{c}0.238 \\
(0.206)\end{array}$ & $\begin{array}{c}0.212 \\
(0.192)\end{array}$ & $\begin{array}{c}0.229 \\
(0.203)\end{array}$ & $\begin{array}{c}0.217 \\
(0.160)\end{array}$ & \\
\hline Left cabinet seats $(\mathrm{t}-1)$ & $\begin{array}{c}0.0297 \\
(0.0233)\end{array}$ & $\begin{array}{c}0.0237 \\
(0.0228)\end{array}$ & $\begin{array}{c}0.0284 \\
(0.0248)\end{array}$ & & $\begin{array}{c}0.0262 \\
(0.0238)\end{array}$ & $\begin{array}{c}0.0238 \\
(0.0203)\end{array}$ & $\begin{array}{c}0.0194 \\
(0.0199)\end{array}$ & $\begin{array}{c}0.0225 \\
(0.0205)\end{array}$ & & $\begin{array}{c}0.0319 \\
(0.0197)\end{array}$ \\
\hline Environmental issue saliency (t-1) & $\begin{array}{l}-0.180 \\
(0.385)\end{array}$ & $\begin{array}{r}-0.0459 \\
(0.370)\end{array}$ & $\begin{array}{l}-0.195 \\
(0.393)\end{array}$ & $\begin{array}{l}-0.192 \\
(0.392)\end{array}$ & $\begin{array}{l}-0.258 \\
(0.393)\end{array}$ & $\begin{array}{l}-0.185 \\
(0.330)\end{array}$ & $\begin{array}{l}-0.117 \\
(0.312)\end{array}$ & $\begin{array}{l}-0.203 \\
(0.332)\end{array}$ & $\begin{array}{l}-0.239 \\
(0.326)\end{array}$ & $\begin{array}{l}-0.281 \\
(0.336)\end{array}$ \\
\hline Election year & $\begin{array}{c}-0.910^{* *} \\
(0.413)\end{array}$ & $\begin{array}{l}-0.833 \\
(0.482)\end{array}$ & $\begin{array}{c}-0.984^{* *} \\
(0.438)\end{array}$ & $\begin{array}{c}-1.016^{* *} \\
(0.445)\end{array}$ & $\begin{array}{c}-0.963^{* *} \\
(0.451)\end{array}$ & $\begin{array}{l}-0.247 \\
(0.312)\end{array}$ & $\begin{array}{l}-0.250 \\
(0.289)\end{array}$ & $\begin{array}{l}-0.299 \\
(0.325)\end{array}$ & $\begin{array}{l}-0.335 \\
(0.299)\end{array}$ & $\begin{array}{l}-0.349 \\
(0.330)\end{array}$ \\
\hline Oil production (t-1) & $\begin{array}{c}0.827 \\
(2.844)\end{array}$ & $\begin{array}{c}0.755 \\
(2.531)\end{array}$ & $\begin{array}{c}0.836 \\
(3.209)\end{array}$ & $\begin{array}{c}0.777 \\
(2.892)\end{array}$ & $\begin{array}{c}0.851 \\
(3.659)\end{array}$ & $\begin{array}{c}0.813^{* * *} \\
(0.131)\end{array}$ & $\begin{array}{c}0.714^{* * *} \\
(0.113)\end{array}$ & $\begin{array}{c}0.817^{* * *} \\
(0.131)\end{array}$ & $\begin{array}{c}0.810^{* * *} \\
(0.132)\end{array}$ & $\begin{array}{c}0.878^{* * *} \\
(0.136)\end{array}$ \\
\hline Inflation (t-1) & $\begin{array}{l}1.143^{*} \\
(0.614)\end{array}$ & $\begin{array}{l}1.029^{* *} \\
(0.450)\end{array}$ & $\begin{array}{l}1.130^{*} \\
(0.598)\end{array}$ & $\begin{array}{l}1.134^{*} \\
(0.578)\end{array}$ & $\begin{array}{l}1.090^{*} \\
(0.622)\end{array}$ & $\begin{array}{c}1.185^{* * *} \\
(0.367)\end{array}$ & $\begin{array}{l}1.108^{* *} \\
(0.418)\end{array}$ & $\begin{array}{c}1.180^{* * *} \\
(0.361)\end{array}$ & $\begin{array}{c}1.148^{* * *} \\
(0.335)\end{array}$ & $\begin{array}{c}1.164^{* * *} \\
(0.340)\end{array}$ \\
\hline
\end{tabular}


Budget deficit (t-1)

Debt (t-1)

Nominal GDP growth (t-1)

VAT rate $(\mathrm{t}-1)$

Country FE

\section{Year FE}

$\mathrm{R}^{2}$ - within

Countries

$N$

Lag structure

Standard errors

\begin{tabular}{cccccccccc}
0.107 & 0.190 & 0.0854 & 0.0625 & 0.183 & 0.285 & $0.326^{*}$ & 0.266 & 0.278 & 0.342 \\
$(0.281)$ & $(0.265)$ & $(0.277)$ & $(0.312)$ & $(0.213)$ & $(0.220)$ & $(0.185)$ & $(0.218)$ & $(0.217)$ & $(0.205)$ \\
$0.154^{*}$ & 0.123 & $0.160^{*}$ & $0.168^{*}$ & $0.145^{*}$ & $0.157^{* *}$ & $0.145^{*}$ & $0.163^{* *}$ & $0.167^{* *}$ & $0.143^{* *}$ \\
$(0.0851)$ & $(0.0884)$ & $(0.0878)$ & $(0.0853)$ & $(0.0807)$ & $(0.0646)$ & $(0.0763)$ & $(0.0663)$ & $(0.0595)$ & $(0.0619)$ \\
$-0.468^{*}$ & $-0.520^{*}$ & $-0.477^{*}$ & $-0.472^{*}$ & $-0.499^{* *}$ & $-0.541^{* * *}$ & $-0.528^{* *}$ & $-0.556^{* * *}$ & $-0.537^{* * *}$ & $-0.606^{* * *}$ \\
$(0.250)$ & $(0.259)$ & $(0.251)$ & $(0.257)$ & $(0.230)$ & $(0.176)$ & $(0.167)$ & $(0.177)$ & $(0.174)$ & $(0.158)$ \\
0.189 & 0.0895 & 0.164 & 0.165 & 0.158 & 0.206 & 0.123 & 0.191 & 0.182 & 0.209 \\
$(0.188)$ & $(0.224)$ & $(0.186)$ & $(0.181)$ & $(0.188)$ & $(0.152)$ & $(0.142)$ & $(0.151)$ & $(0.147)$ & $(0.152)$ \\
\hline Yes & Yes & Yes & Yes & Yes & Yes & Yes & Yes & Yes & Yes \\
Yes & Yes & Yes & Yes & Yes & Yes & Yes & Yes & Yes & Yes \\
0.757 & 0.774 & 0.759 & 0.762 & 0.765 & 0.762 & 0.775 & 0.763 & 0.772 & 0.771 \\
20 & 20 & 20 & 20 & 20 & 20 & 20 & 20 & 20 & 20 \\
401 & 401 & 401 & 401 & 401 & 412 & 412 & 412 & 412 & 412 \\
& & & & & Two year & & \\
& & & & & & &
\end{tabular}

Note: ${ }^{*} p<0.10,{ }^{* *} p<0.05,{ }^{* * *} p<0.01$ 
Table A5. Robustness tests (2)

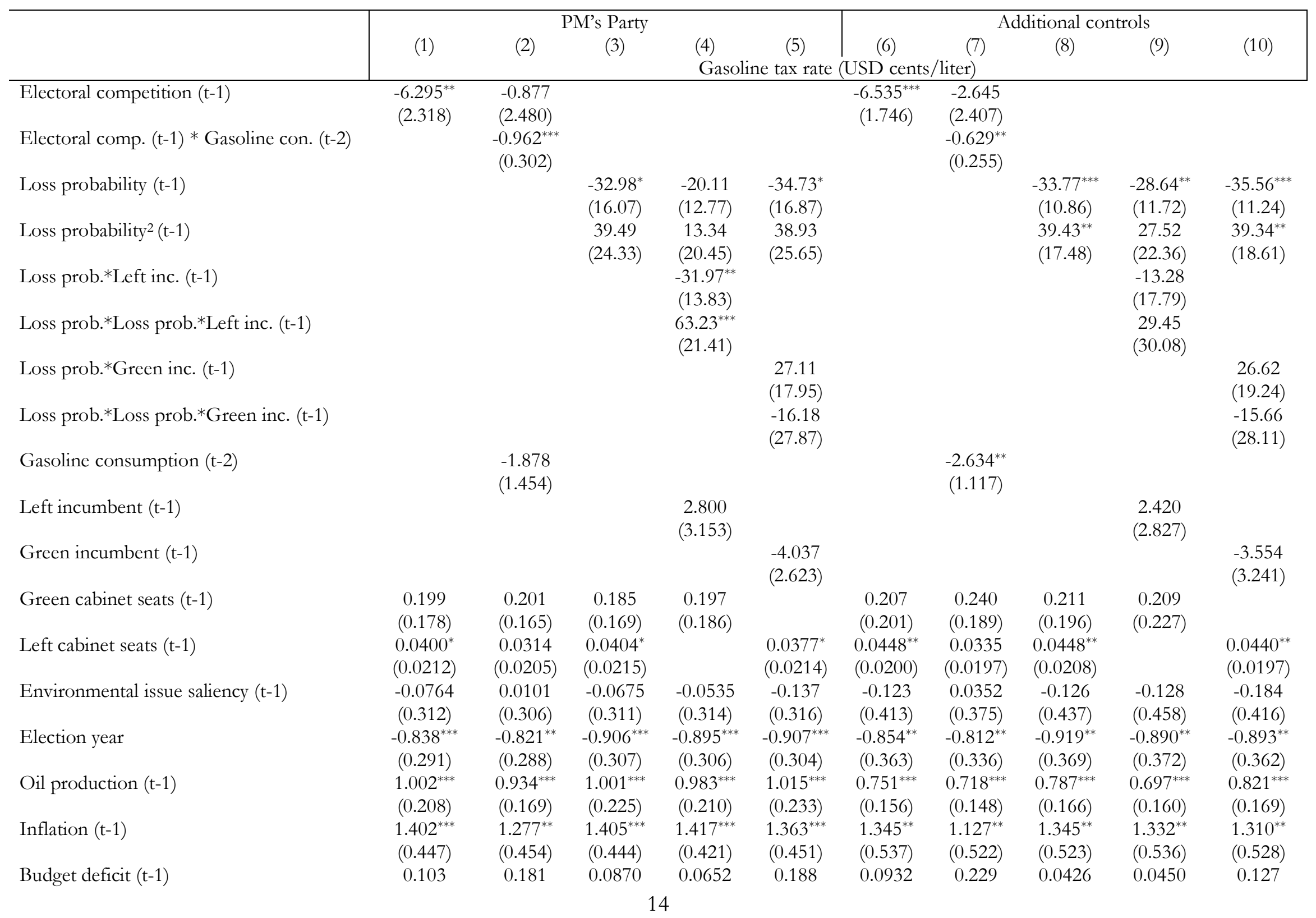


Debt (t-1)

Nom. GDP growth (t-1)

VAT rate (t-1)

Nom. GDP per capita (t-1)

Green v. growth ideology (t-1)

Left v. right ideology (t-1)

Single party (t-1)

Political constraints ( $\mathrm{t}-1)$

Social expenditure (t-1)

Urbanization (t-1)

Income tax (t-1)

EU membership (t-1)

Kyoto Protocol ratification (t-1)

\section{$(0.204)$}

$0.176^{* *}$

(0.0699)

$-0.612^{* *}$

(0.221)

0.209

(0.157)

(0.182)

$0.140^{*}$

(0.0731)

(0.208)

0.108
$(0.175)$

$0.175)$
$(0.108$

(0.206)

$0.187^{\text {** }}$

(0.0714)

$-0.619^{* *}$

(0.223)

(0.160)
$-0.653^{* * *}$

0.175
$(0.160)$
(0.239)

$0.197^{* * *}$

$(0.0648)$

$-0.619^{* *}$

(0.231)

0.179

(0.158)
(0.193)

$0.169^{* *}$

$-0.640^{* * *}$

(0.203)

0.169

(0.162)

(0.186)

$-4.465$

(2.720)

$-0.0184$

(0.151)

0.282

(0.174)

$-0.364$

(2.158)

$-0.0630$

(11.87)

$-0.217$

(0.510)

0.380

(0.513)

$-0.383$

(0.387)

0.738

(4.371)

$12.05^{\text {*** }}$

(2.119)

Country FE
Year FE

$\mathrm{R}^{2}$ - within

Countries

N

Yes

Yes Yes

Yes Yes

0.757

20
.761
20

373
Yes Yes

$0.772 \quad 0.761$

$373 \quad 20$

Yes Yes

Yes

Yes

Yes
0.777

0.766

20

$373 \quad 390$

$\begin{array}{llll}(0.197) & (0.196) & (0.247) & (0.191)\end{array}$

$0.156^{* *} \quad 0.185^{* * *} \quad 0.187^{* * *} \quad 0.169^{* *}$

$\begin{array}{llll}(0.0584) & (0.0625) \quad(0.0617) \quad(0.0621)\end{array}$

$\begin{array}{llll}-0.586^{* *} & -0.444 & -0.435 & -0.455^{*}\end{array}$

$\begin{array}{llll}(0.272) & (0.263) & (0.277) & (0.246)\end{array}$

$\begin{array}{llll}-0.0299 & 0.0212 & 0.0347 & -0.00116\end{array}$

$\begin{array}{llll}(0.180) & (0.184) & (0.191) & (0.196)\end{array}$

$\begin{array}{llll}-2.745 & -4.572^{*} & -4.445 & -3.644\end{array}$

(2.778)

$-0.0824$

(0.163)

0.306

(0.179)

1.243

(2.179)

2.387

(12.22)

$-0.422$

(0.470)

0.610

(0.422)

$-0.373$

(0.387)

0.844

(4.294)

$8.545^{* * *}$

(2.596)

0.0194

(2.695)

$-0.000574$

(2.672)

(0.148)

(0.140)

0.240

0.0157

(0.182)

(0.214)

0.264

(2.341)

2.785

(12.16)

$-0.180$

(0.554)

$(0.516)$

0.368

0.379

(0.506)

$-0.357$

(0.523)

$-0.298$

(0.387)

(0.417)

0.945

1.260

(4.569)

$12.08^{* * *}$

(0.150)

0.296

(0.178)

$-0.377$

(2.384)

5.080

(11.32)

$-0.0386$

(0.509)

0.365

(0.491)

$-0.406$

(0.403)

1.521

(4.111)

$(1.563)$

(2.147)

Yes Yes

Yes

Yes

Yes

$12.84^{* * *}$

Yes

20

$390 \quad 20$

390

Yes
0.781

Yes

Yes
0.787

20 
Table A6. Robustness tests (3)

\begin{tabular}{|c|c|c|c|c|c|c|c|c|}
\hline & \multicolumn{2}{|c|}{ Logit } & \multirow{2}{*}{$\begin{array}{c}\begin{array}{c}\text { Alternative measure } \\
\text { of personal costs }\end{array} \\
\text { (3) } \\
\text { Gasoline tax rate } \\
\text { (USD cents/liter) }\end{array}$} & \multicolumn{5}{|c|}{ Alternative DV } \\
\hline & $\begin{array}{l}\text { (1) } \\
\text { Tax in }\end{array}$ & $\begin{array}{l}(2) \\
\text { rease }\end{array}$ & & (4) & (5) & $\begin{array}{c}\text { (6) } \\
\Delta \text { in tax ra }\end{array}$ & (7) & $(8)$ \\
\hline Electoral competition (t-1) & $\begin{array}{l}-0.932^{*} \\
(0.536)\end{array}$ & $\begin{array}{c}0.626 \\
(0.996)\end{array}$ & $\begin{array}{c}5.566 \\
(3.511)\end{array}$ & $\begin{array}{c}-3.780^{* *} \\
(1.788)\end{array}$ & $\begin{array}{c}5.683^{* * *} \\
(1.376)\end{array}$ & & & \\
\hline Electoral comp. $(\mathrm{t}-1) *$ Gasoline con. $(\mathrm{t}-2)$ & & $\begin{array}{l}-0.284^{*} \\
(0.164)\end{array}$ & & & $\begin{array}{c}-1.708^{* * *} \\
(0.313)\end{array}$ & & & \\
\hline Electoral comp. $(\mathrm{t}-1) *$ Gasoline expend. $(\mathrm{t}-2)$ & & & $\begin{array}{c}-1804.9^{* * *} \\
(576.2)\end{array}$ & & & & & \\
\hline Loss probability $(\mathrm{t}-1)$ & & & & & & $\begin{array}{l}-17.66 \\
(12.76)\end{array}$ & $\begin{array}{l}-6.626 \\
(11.77)\end{array}$ & $\begin{array}{l}-17.95 \\
(13.30)\end{array}$ \\
\hline Loss probability $^{2}(\mathrm{t}-1)$ & & & & & & $\begin{array}{c}19.50 \\
(20.78)\end{array}$ & $\begin{array}{l}-3.046 \\
(17.11)\end{array}$ & $\begin{array}{c}18.39 \\
(21.58)\end{array}$ \\
\hline Loss prob. $*$ Left inc. $(\mathrm{t}-1)$ & & & & & & & $\begin{array}{l}-34.35 \\
(30.53)\end{array}$ & \\
\hline Loss prob. ${ }^{*}$ Loss prob. $*$ Left inc. $(\mathrm{t}-1)$ & & & & & & & $\begin{array}{c}63.60 \\
(46.26)\end{array}$ & \\
\hline Loss prob. ${ }^{*}$ Green inc. $(\mathrm{t}-1)$ & & & & & & & & $\begin{array}{c}0.844 \\
(24.06)\end{array}$ \\
\hline Loss prob.*Loss prob. ${ }^{*}$ Green inc. $(\mathrm{t}-1)$ & & & & & & & & $\begin{array}{c}10.76 \\
(34.91)\end{array}$ \\
\hline Gasoline consumption ( $\mathrm{t}-2)$ & & $\begin{array}{l}0.578^{*} \\
(0.316)\end{array}$ & & & $\begin{array}{c}1.286 \\
(1.254)\end{array}$ & & & \\
\hline Gasoline expenditure ( $\mathrm{t}-2)$ & & & $\begin{array}{c}422.8 \\
(756.3)\end{array}$ & & & & & \\
\hline Left incumbent $(\mathrm{t}-1)$ & & & & & & & $\begin{array}{c}0.727 \\
(3.134)\end{array}$ & \\
\hline Green incumbent $(\mathrm{t}-1)$ & & & & & & & & $\begin{array}{l}-0.928 \\
(2.463)\end{array}$ \\
\hline Green cabinet seats $(\mathrm{t}-1)$ & $\begin{array}{c}0.0888^{*} \\
(0.0534)\end{array}$ & $\begin{array}{c}0.0824 \\
(0.0544)\end{array}$ & $\begin{array}{l}0.288^{*} \\
(0.158)\end{array}$ & $\begin{array}{c}0.120 \\
(0.212)\end{array}$ & $\begin{array}{l}0.0797 \\
(0.215)\end{array}$ & $\begin{array}{c}0.118 \\
(0.217)\end{array}$ & $\begin{array}{c}0.111 \\
(0.226)\end{array}$ & \\
\hline Left cabinet seats $(\mathrm{t}-1)$ & $\begin{array}{c}0.00438 \\
(0.00402)\end{array}$ & $\begin{array}{c}0.00464 \\
(0.00406)\end{array}$ & $\begin{array}{c}0.0270 \\
(0.0193)\end{array}$ & $\begin{array}{c}-0.00894 \\
(0.0224)\end{array}$ & $\begin{array}{r}-0.00965 \\
(0.0217)\end{array}$ & $\begin{array}{r}-0.00954 \\
(0.0224)\end{array}$ & & $\begin{array}{l}-0.0101 \\
(0.0224)\end{array}$ \\
\hline Environmental issue saliency $(\mathrm{t}-1)$ & $\begin{array}{c}0.0373 \\
(0.0529)\end{array}$ & $\begin{array}{c}0.0228 \\
(0.0545)\end{array}$ & $\begin{array}{c}-0.0941 \\
(0.370)\end{array}$ & $\begin{array}{l}0.0104 \\
(0.219)\end{array}$ & $\begin{array}{c}0.00865 \\
(0.218)\end{array}$ & $\begin{array}{c}-0.00437 \\
(0.222)\end{array}$ & $\begin{array}{c}-0.0368 \\
(0.216)\end{array}$ & $\begin{array}{l}-0.0353 \\
(0.221)\end{array}$ \\
\hline Election year & -0.0874 & -0.0903 & $-0.849^{* *}$ & -0.881 & -0.943 & -0.929 & $-1.087^{*}$ & -0.930 \\
\hline
\end{tabular}


Oil production (t-1)

Inflation (t-1)

Budget deficit (t-1)

Debt (t-1)

Nom. GDP growth (t-1)

VAT rate (t-1)

Gas excise tax rate (t-1)

\section{Country FE}

Year FE

$\mathrm{R}^{2}$ - within

Countries

N

\begin{tabular}{cccccccc}
$(0.278)$ & $(0.281)$ & $(0.403)$ & $(0.615)$ & $(0.584)$ & $(0.608)$ & $(0.611)$ & $(0.608)$ \\
-0.0748 & -0.114 & $0.824^{* * *}$ & 0.242 & 0.157 & 0.254 & 0.271 & 0.265 \\
$(0.146)$ & $(0.148)$ & $(0.179)$ & $(0.191)$ & $(0.176)$ & $(0.195)$ & $(0.213)$ & $(0.192)$ \\
$0.160^{*}$ & $0.189^{*}$ & $1.249^{* *}$ & $1.167^{*}$ & $1.250^{*}$ & $1.167^{*}$ & $1.215^{*}$ & $1.165^{*}$ \\
$(0.0959)$ & $(0.0979)$ & $(0.543)$ & $(0.653)$ & $(0.679)$ & $(0.654)$ & $(0.634)$ & $(0.655)$ \\
0.0747 & 0.0678 & 0.117 & $0.432^{* *}$ & $0.441^{* *}$ & $0.417^{* *}$ & $0.391^{*}$ & $0.449^{*}$ \\
$(0.0583)$ & $(0.0591)$ & $(0.175)$ & $(0.205)$ & $(0.177)$ & $(0.197)$ & $(0.205)$ & $(0.225)$ \\
-0.00494 & 0.00112 & 0.108 & 0.0284 & 0.0419 & 0.0320 & 0.0436 & 0.0288 \\
$(0.0116)$ & $(0.0122)$ & $(0.0695)$ & $(0.0518)$ & $(0.0550)$ & $(0.0557)$ & $(0.0563)$ & $(0.0537)$ \\
-0.0697 & -0.0512 & -0.275 & -0.0269 & 0.0315 & -0.0369 & -0.0566 & -0.0506 \\
$(0.0673)$ & $(0.0679)$ & $(0.221)$ & $(0.207)$ & $(0.206)$ & $(0.207)$ & $(0.205)$ & $(0.189)$ \\
0.0220 & 0.0128 & 0.120 & 0.0928 & 0.0182 & 0.0829 & 0.117 & 0.0898 \\
$(0.0322)$ & $(0.0331)$ & $(0.210)$ & $(0.167)$ & $(0.167)$ & $(0.163)$ & $(0.169)$ & $(0.157)$ \\
$-0.0668^{* * *}$ & $-0.0610^{* *}$ & & $-0.480^{* * *}$ & $-0.510^{* * *}$ & $-0.483^{* * *}$ & $-0.513^{* * *}$ & $-0.494^{* * *}$ \\
$(0.0224)$ & $(0.0237)$ & & $(0.160)$ & $(0.162)$ & $(0.165)$ & $(0.171)$ & $(0.165)$ \\
\hline Yes & Yes & Yes & Yes & Yes & Yes & Yes & Yes \\
Yes & Yes & Yes & Yes & Yes & Yes & Yes & Yes \\
20 & & 0.760 & 0.294 & 0.316 & 0.296 & 0.307 & 0.297 \\
387 & 20 & 20 & 20 & 20 & 20 & 20 & 20 \\
\hline
\end{tabular}

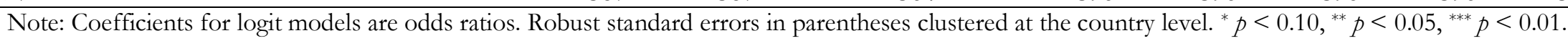

